UNITED STATES DEPARTMENT OF THE INTERIOR

GEOLOGICAL SURVEY

Report on Televiewer Log and Stress Measurements
in Core Hole USW-G1, Nevada Test Site
December 13-22, 1981

By

J. H. Healy1, S. H. Hickman1, M. D. Zoback1, W. L. E11 is'2

Open-File Report 84-15

This report is preliminary and has not been reviewed for conformity with U.S. Geological Survey editorial standards and stratigraphic nomenclature. Any use of trade names is for descriptive purposes only and does not imply endorsement by the USGS.

1 Menlo Park, CA 94025

2 Denver, CO 80225 
Introduction .......................... 1

Borehole Televiewer Studies. . . . . . . . . . . . . . . 1

Summary of Borehole Televiewer Results. . . . . . . . 8

The Measurement of the Earth's Tectonic Stress Field . . . . . . 8

Hydrofrac Stress Measurements. ................. . y

Description of the Stress Field............. y

Vertical Stress.................... 9

Least Horizontal Stress.................. 10

Greatest Horizontal Stress................ 10

Results.............................. 11

Drilling-Induced Fractures. . . . . . . . . . . . . . 11

Potential Faulting. .................... 11

References ........................ 16

Appendix I . . . . . . . . . . . . . . . . . . 17

operations. . . . . . . ........... 17

Chronological Log of Operations ............. 17

Appendix II. . . . . . . . . . . . . . . . . . $2 b$

Televiewer logs................... . . 26

Table I. Summary of stress measurements. . . . . . . . 45

Appendix III . . . . . . . . . . . . . . . . . . 46

Density measurement and vertical stress.......... 40

Table II. Density measurements in USW-H1 . . . . . . . 47 
Figures

Page

1. a) Isometric sketch of fracture or bedding plane intersecting borehole and corresponding borehole televiewer log;

b) Televiewer picture from 571 to $587 \mathrm{~m}(1,875$ ro $1, y 25 \mathrm{ft})$, USW-G1 borehole, showing vertical drilling-induced fracture, borehole ellipticity, and sinusoidal trace of dipping fracture; c) Televiewer picture from 617 to $632 \mathrm{~m}(2,025$ to $2,075 \mathrm{ft})$ showing near vertical $\left(+89^{\circ}\right.$ dip) fracture exiting borenole.... 3

2. Log showing major features (vertical fractures, highly fractured intervals, and hole ellipticity) observed on televiewer $10 \mathrm{~g}$. Stratigraphy, static water level, and known fault zones identified from core al so shown . . . . . . . . . . ....

3. Strike distribution of fractures dipping $85^{\circ}$ or more as determined from USW-G1 televiewer log........... 5

4. Azimuth of drilling-induced fractures and inferred hole ellipticity measured from televiewer log. Magnetic north, deviation $16^{\circ} \mathrm{E}$.

5. Rose diagram showing orientation of nole ellipticity within the a) Calico Hills, Prow Pass, and Bullfrog units, b) Tram unit, c) Flow Breccia, and d) Litnic-ricn tuff. Orientations were measured for 3-m-long zones in which ellipticity was well defined and the wall rock was relatively unfracturea ... 7

6. Downhole pressure and flow data for hydraulic fracturing stress measurements in USW-G1. Values chosen for $S_{n}$ are indicated . . 12

7. Least principal compressive stress, $S_{n}$, as a function of depth. The vertical stress (1itnostat) and pore pressure at deptn are shown for reference ............... 13

8. Geologic map of Yucca Mountain area snowing direction of least horizontal principal stress as inferred from hydrofracture data

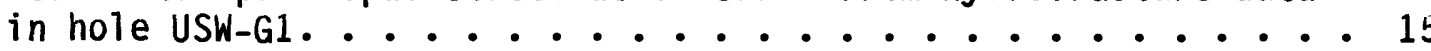


Introduction

This document describes the operations and the preliminary results of televiewer logging and stress measurements in USW-G1 on Yucca Mountain at tne Nevada Test Site, Nevada, Carried out between December 13 and December 22, 1981. We anticipate that additional measurements in this area will be made in the future and a more complete interpretation of these data will be attempted.

USW-G1 is a core hole drilled on the eastern flank of Yucca Mountain at Nevada coordinates $N-770,500, E-561,000$. The hole was drilled to evaluate the site as a potential repository for radioactive waste. The work reported here is part of an array of geological, geophysical, and hydrologic studies designed to provide data needed for the evaluation of a potential nuclear waste repository. Information on the state of stress in the rocks is needed for the design and construction of a repository, for the prediction of long-term tectonic stability of the region, and for the evaluation of the hydrologic properties of the site.

The stress measurements are made using the hydrofrac method. This method involves isolating a short section of the borehole detween two rubber packers and then fracturing the rock in this section with fluid pressure applied through drilling pipe or tubing from the surface. The shape of the pressurevolume time curves can be used to infer the state of stress. An ultrasonic Dorehole televiewer is used to locate unfractured sections of the borenole suitable for stress measurements. Orientations of the induced fractures are determined from the post-frac televiewer logs or from impression packers that are used when the televiewer records do not show the fractures.

This report consists of two sections descrioing the televiewer logs ana the stress measurements and an appendix descrioing the operations. In anticipation of additional research at this site we discuss the operations in detail in the appendix and make suggestions for improvements in techniques for future stress measurements. Because of the variadility of rock properties ana stress in a borehole, it is important to make many measurements to assure a meaningful description of the stress field and its variations. Stress measurements require the use of a drill rig and crew, and the number of these measurements that can be made in a borehole is determined by available rig time and the efficiency of the operation.

\section{Borehole Televiewer Studies}

The borehole televiewer survey of hole USW-G1 provides important data on natural fractures, drilling-induced hydraulic fractures, and stress-induced hole ellipticity. The hole was logged from 1,325 to $451 \mathrm{~m}$, the level of fluid in the hole.

The borehole televiewer is a downhole logging tool consisting of a rotating acoustic transducer that emits pulses focused in a $3^{\circ}$ beam at a rate of 1,800 pulses per second. Zemanek et a1. (1970) describe the operation of the tool in detail. The transducer rotates at three revolutions per second as the tool moves slowly up the hole at a speed of $2.5 \mathrm{~cm} / \mathrm{s}$. The amplitude of the reflected acoustic pulse is plotted as brigntness on a three-axis oscilloscope as a function of beam azimuth and vertical position in the hole. The 
oscilloscope display is photograpned to make a record of the adta and tne raw data are also recorded on a video tape. The scope trace is triggered at magnetic north by a flux gate magnetometer in the tool so that the orientation of observed features can be determined. Essentially the smoothness of the borehole wall is mapped. Where the smootinness of the vorehole wall is perturbed by a planar feature such as a fracture, a dark sinusoidal pattern is seen. Figure 1a shows conceptually how the televiewer portrays planar fractures as sinusoids and Figures $1 \mathrm{~b}$ and $1 \mathrm{c}$ show two of the drilling-induced hydraulic fractures from hole USW-G1. Other fractures are also seen at several depths in the hole.

Resolution of the borehole televiewer depends upon hole diameter, wall conditions, reflectivity of the formation, and acoustic impedance of the well bore fluid. The wall condition is the most important factor, as a rough well bore makes detection of fine features quite difficult. The extreme norizontal exaggeration in the data (approximately 10:1 in figs. 1b, 1c) makes fractures dipping $<50^{\circ}$ appear to De approximately horizontal.

The most striking aspect of the televiewer data is the discovery of extensive drilling-induced hydraulic fractures in the well (figs. 1b, lc). The deptins and orientations of these fractures were taken from the photograpns (app. II) and are plotted in Figures 2 and 4. Another compilation of all fractures with dip greater tnan $85^{\circ}$ is presented in Figure 3 . The conclusion that these fractures were induced by drilling rests primarily on tne very low probability of intersecting a natural fracture exactly centered on the vorenole and naving almost perfect symmetry about the borehole axis for tens of meters. The absence of corresponding fractures in tne core snows that the fractures formed after the core nad been cut from the drill nole. The arilling-induced nydraulic fractures have a strike of $N 25^{\circ} \mathrm{E} \pm 10^{\circ}$ (fig. 4 ). The direction of least horizontal compression is perpendicular to these fractures, about Nob"W.

Several fault zones were identified from the core of the hole (Spengler et a1., 1981) and are clearly seen in the televiewer data. Numerous fracture zones are also observed in the 10gs. Some of these fracture zones correlate with fracture zones observed in the core, for example, that extending from 703 to $725 \mathrm{~m}$. A detailed cross-correlation between the televiewer data, the core, and other geophysical logs had not been completed at the time that tnis report was prepared.

Other striking features in the televiewer data are the dark vertical bands occurring in pairs and centered $180^{\circ}$ apart. These Dands are cnaracterized by fuzzy edges suggesting that they are not a result of scratching or rubbing of bits or drill steel on the side of the hole. Where these bands and trie drilling-induced fractures occur in the same section of the borehole the dark bands are oriented $90^{\circ}$ from the drilling-induced fractures. Based on these observations we infer that the dark bands are in some way related to stressinduced spalling of the borenole wall, a feature that has veen ouserved in many noles and is now thought to be a reliable indicator of the principal stress directions (Bell and Gough, 1979). Additiunal research on the origin of tnese features is now in progress (Zoback et a1., 1982). But even witnout a complete detailed explanation of the origin of these dark Danas, the systenatic relation between the orieritation of induced fractures and the bands (fig. 5) 1eads us to believe that the bands do indicate hole ellipticity and are a reliable inaicator of stress direction. 


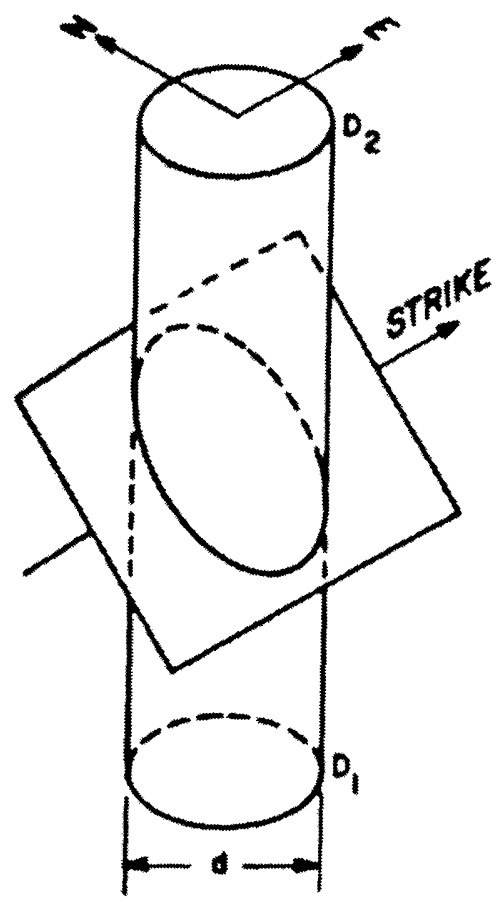

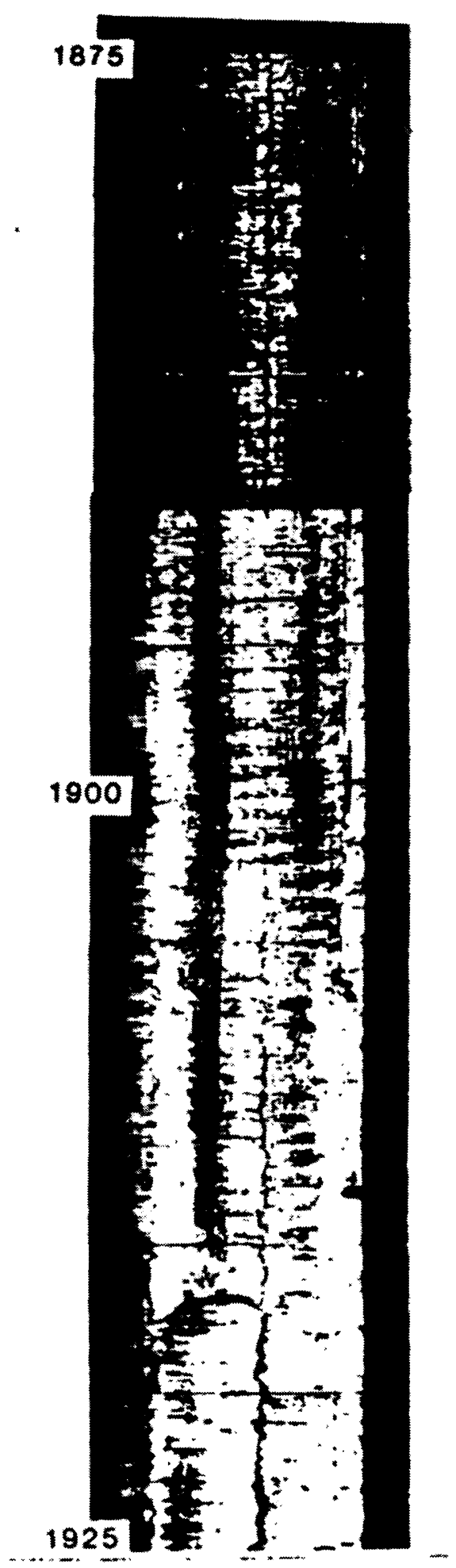

(b)

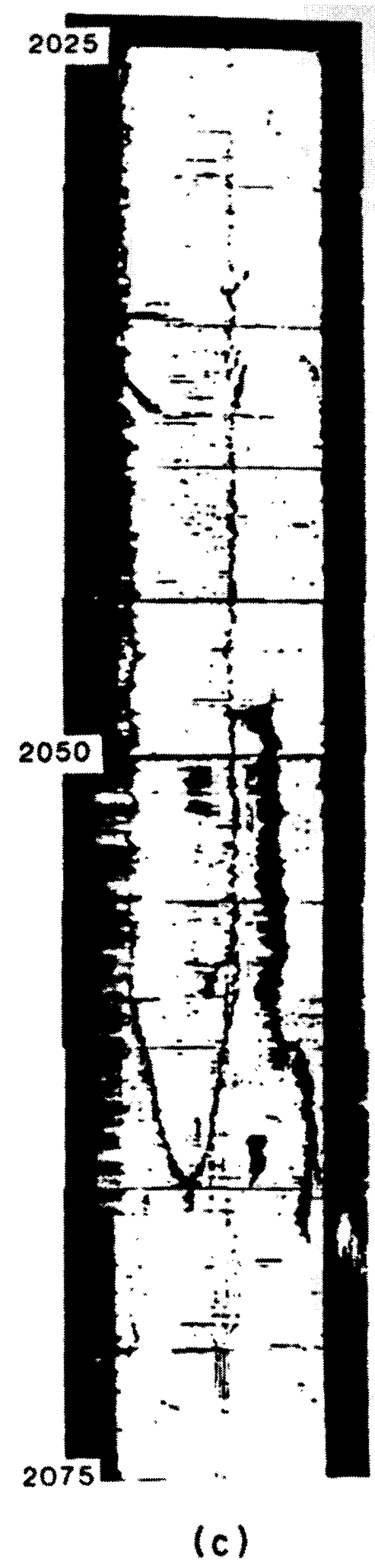

(c)

Figure 1. a) Isometric sketch of fracture or bedding plane intersecting borehole and corresponding borenole televlewer $\log$ [after Zemanek et al. (1969), fig. 7J;

b) Televiewer picture from 571 to $587 \mathrm{~m}(1,875$ to $1,925 \mathrm{ft})$, USW-61 borehole, showing vertical drilling-induced fracture, borenole ellipticity, and sinusoidal trace of dipping fracture:

c) Televiewer picture from 617 to 632 m $(2,025$ to $2,075 \mathrm{ft})$ snowing near vertical $\left(+89^{\circ}\right.$ dip) fracture exiting borehole. 


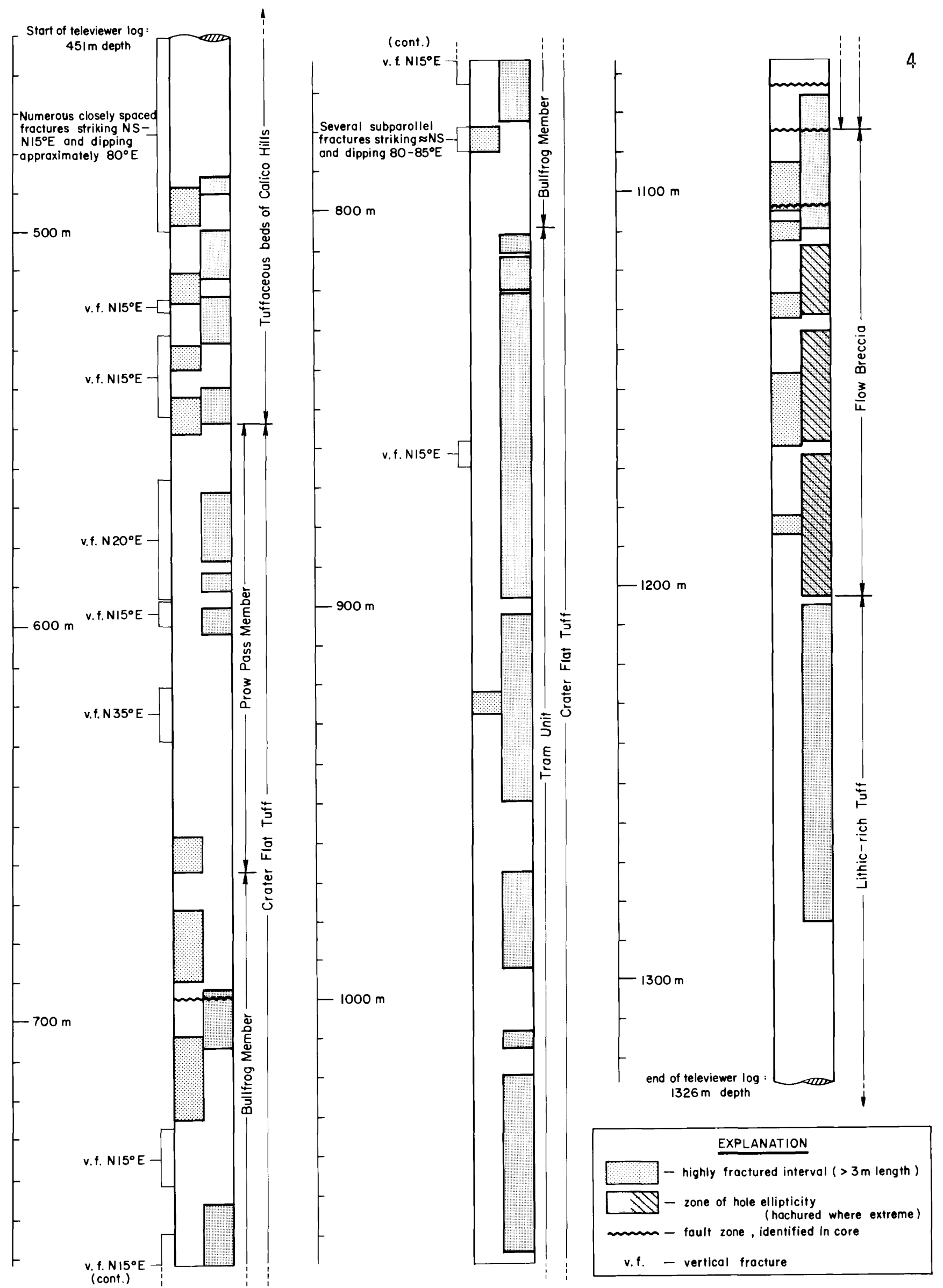

Figure 2. Log showing major features (vertical fractures, nignly fracturea intervals, and hole ellipticity) observed on televiewer log. Stratigraphy, static water level, ana known fault zones identified from core also snown. 


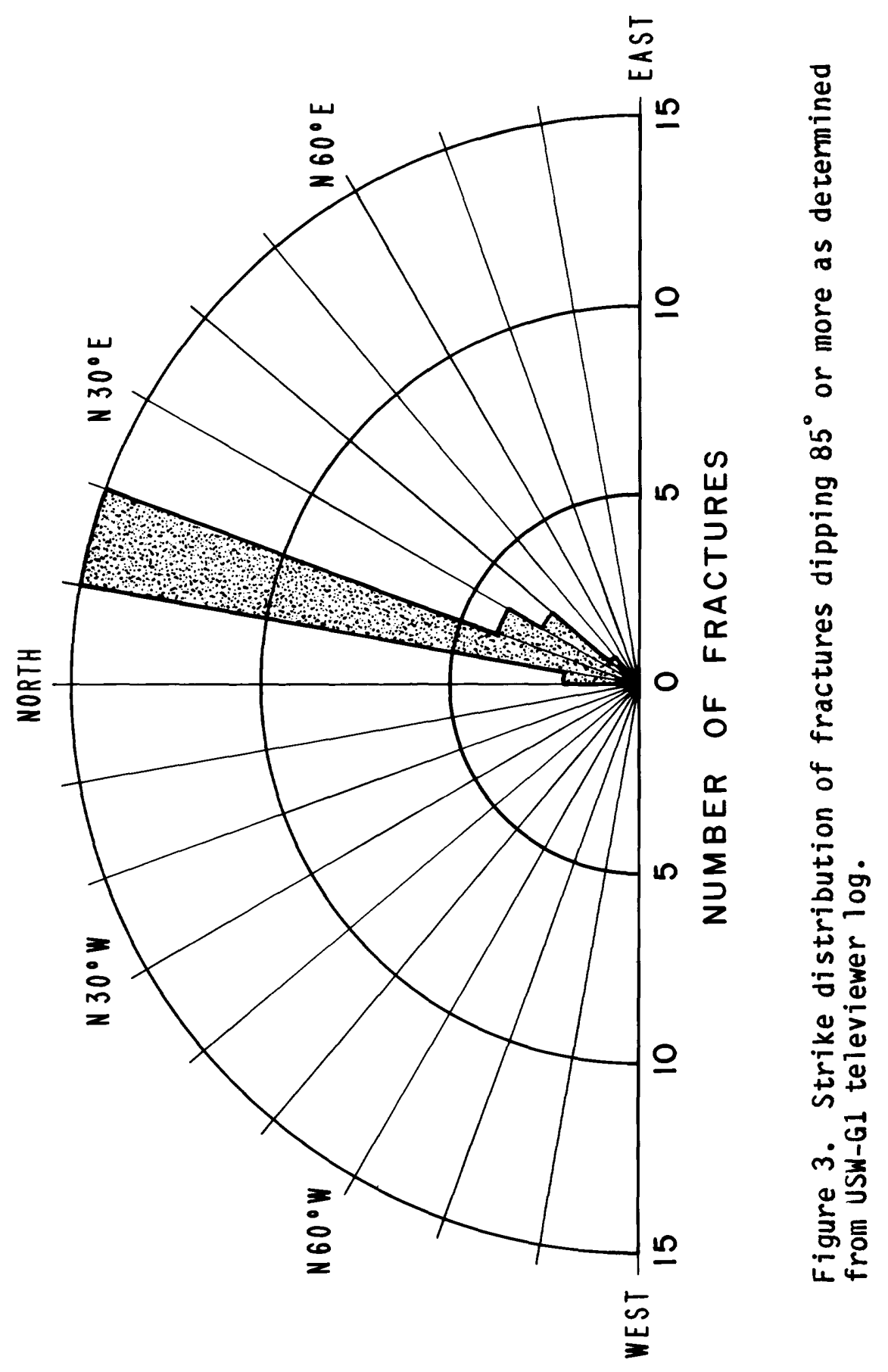


Figure 4. Azimuth of drilling-induced fractures (solid lines) and inferred hole ellipticity (dots) measured from televiewer log (Appendix II). Magnetic north, deviation $16^{\circ} \mathrm{E}$. (see platt) 

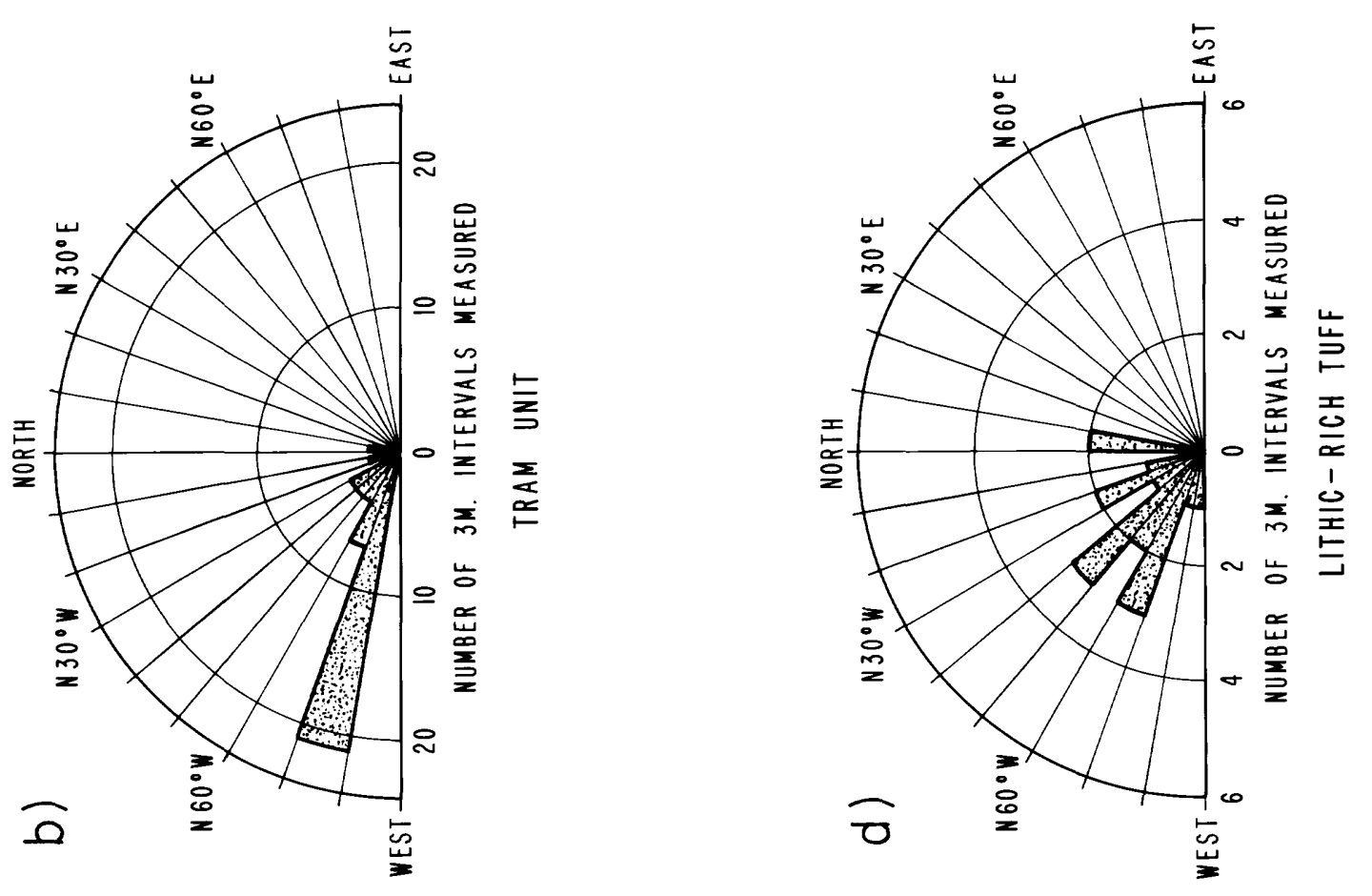

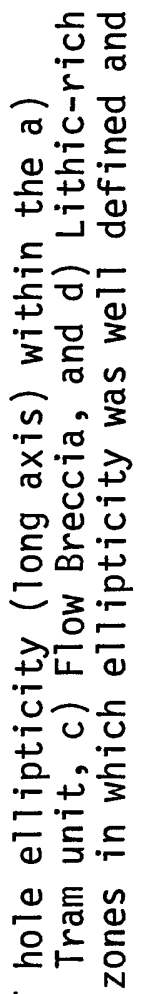
능 잉

ธิ์
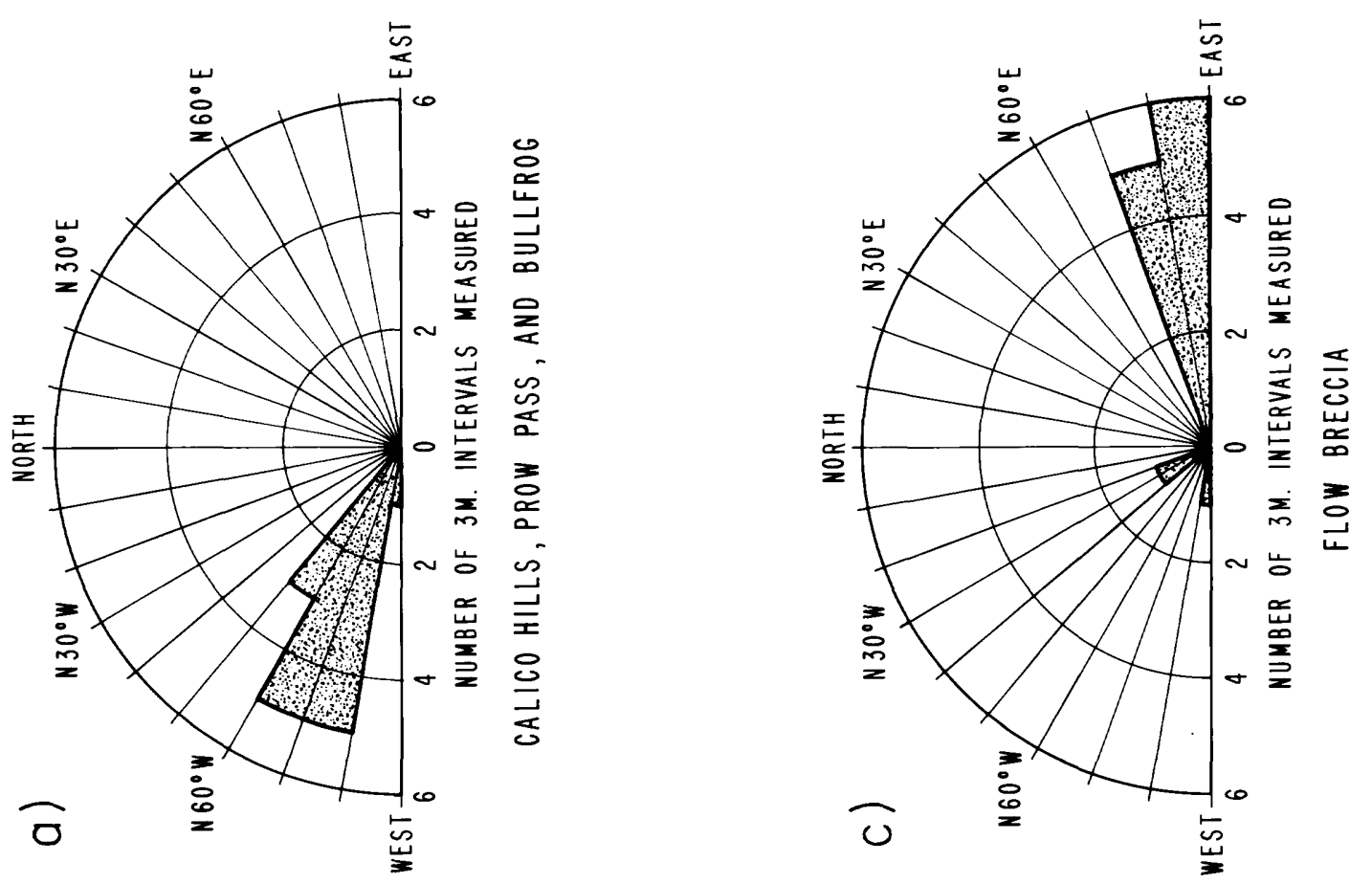

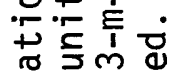

동횧 . 눈 옹ำ 긍믈 包 的宁导

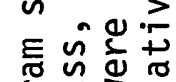
ธิธี 궁 농 这望尔 叫 으늘 เำ敦 웅.

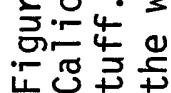


The ellipticity data from the Calico Hills, Prow Pass, Bullfrog, and Tram units are very strongly grouped and suggest that the direction of least horizontal compression is WNW-ESE (fig. 5), supporting the nydraulic fracturing data presented in Figure 3. The orientation of fractures in the flow breccia unit from 1,085 to $1,203 \mathrm{~m}$ in the nole is systematically different from the orientation of fractures in the units above. This could be the result of a change in stress direction in that zone, a significant change in rock mecnanical properties, or the lack of a well controlled stress concentration around the hole due to the relatively poor rock quality in that interval. The data in the Lithic Ridge Tuff (from 1,203 to 1,326 m) are more scattered than in the units above but are generally consistent with WNW-ESE extension.

Summary of Borehole Televiewer Results

The discovery of extensive drilling-induced hydraulic fractures in USW-G1 provides a simple solution to the hydrologic questions raised by the odservation that fluid could not be recirculated to the surface during drilling. The orientation of the arilling-induced hydraulic fractures yields tne direction of the in situ stress field (the direction of least horizontal compression is $\mathrm{N} 65^{\circ} \mathrm{W}$ ), which is corroborated by the majority of data on nole ellipticity. Furthermore, the televiewer data provide detailed information on the locations of potentialiy permeable fracture and fault zones in the nole, the deptns of these zones, their thicknesses, and their attitudes.

\section{The Measurement of the Earth's Tectonic Stress Field}

In the following section we comment on the origin and measurement of the Eartn's stress field. We want to emphasize that the stress field at a particular site is related to regional or global geologic processes that tend to persist for millions of years.

Stresses generated by the convecting interior of the planet drive the continuing geologic evolution of the earth, producing earthquakes and volcanic activity, and over long periods of time reshape the Earth's surface, producing new mountain ranges and sedimentary basins. This process, which in many places seems to be 1 imited only by the strength of crustal rocks, produces large stresses in the Earth's crust. The measurement of these stresses is an important objective of fundamental research in geology. The stress field is a critical variable in pnysical models that attempt to describe the Eartn's tectonic processes and predict the future course of geologic evolution.

When methods are developed to measure and map the tectonic stress field on a regional basis, the data will have important practical applications in addition to their significance for basic research in geology. Tnese practical applications include earthquake prediction, exploration for deep geothermal resources, site selection and engineering of deep excavations, modeling of fluid flow in crystalline rocks, and the development of mineral recovery techniques by circulating fluids tnrough induced fracture systems. 
Early research on the measurement of stress was carried out in quarries and mines where investigators could use laboratory instrumentation to measure the rock deformation resulting from the removal of fresh rock from an instrumented volume. A number of successful techniques were developed and important data were obtained that demonstrate the value of this research. But these methods are restricted to locations where deep mines are accessible to research workers or to measurements near the Earth's surface where active processes distort the stress field.

The measurement of stress in deep boreholes avoids many of the prodems encountered near the surface and, in principle, gives researcners tne opportunity to obtain data from many locations. Methods for measuring stress in boreholes have been under development for more than 15 years, and of the various methods that have been tested, the hydraulic fracturing method of stress measurement has shown the greatest promise. The data from this technique have a satisfactory internal consistency and correlate with other indicators of the Eartn's stress field (Zodack and ZoDack, 1y80).

\section{Hydrofrac Stress Measurements}

The measurement of stress with the hydraulic fracturing tecnnique is conceptually simple. It involves sealing off a short section of the borehole so that the fluid pressure can be increased in the sealed interval without affecting the pressure above or below the interval. Tubing connects the sealed interval with pumps and instruments on the surface so that fluid can be pumped into the interval with precisely measured and controlled volumes and pressures. By pumping fluid into the interval at a constant rate of flow the pressure is increased until the rock fractures. Stress is determined from the pressure-volume time nistory during the fracture process.

Description of the Stress Field

Near the surface of the Earth the stress field is usually oriented along axes that are perpendicular and parallel to the surface. Tnis means tnat in most places stress can be determined by measuring the compressive stress along three perpendicular axes:

The axis of vertical stress, $S_{V}$

The axis of least horizontal stress, $S_{h}$

The axis of greatest horizontal stress, $S_{H}$

Vertical Stress, $S_{V}$

The vertical stress is determined by the weight of the overlying rocks. It usually can be estimated with good accuracy even without special logs or measurements on the core. Thus, it is the easiest to obtain and the most reliable of the three stress values. 
Least Horizontal Stress, $S_{n}$

The least horizontal stress can be measured with good accuracy by determining the pressure required to hold open a fracture generated in a borehole.

On Yucca Mountain, as in most of Nevada, $S_{h}$ is less than $S_{v}$ and, of course, less than $S_{H}$, so that less energy is required to open a fracture that is perpendicular to $S_{n}$. Even when the initial directions of fracture propagation are controlled by preexisting fractures or other irregularities in the borehole, the fracture will usually turn to orient itself perpendicular to the least stress. If the rocks are impermeable, the least stress is easily obtained by observing the pressure when the pumps are turned off after the rocks have been fractured and the fracture extended by pumping a suitable volume of water. If the rocks are highly permeable, additional analysis may be required to separate the effects of whole rock permeability from the fracture permeability, but this is usually a straight forward matter as the hydrologic characteristics of the isolated interval change dramatically at pressures near the value of $S_{n}$.

Greatest Horizontal Stress, $S_{H}$

The greatest horizontal stress is the most difficult of the tnree principal stresses to measure reliably. Its determination is Dased on an analysis of fracturing in boreholes by Hubbert and Willis (1957). A straight forward algebraic manipulation of their results leads to the equation

$$
P_{f}=3 S_{n}-S_{H}+T-P
$$

which relates the pressure required to initiate a fracture in a vertical borehole, $P_{f}$, to the horizontal stresses, $S_{h}$ and $S_{H}$, the tensile strength, $T$, and the pressure of pore fluids in the rocks surrounding the borehole, P. Strictly speaking, this equation is applicable only to a borehole in an isotropic, homogeneous medium witnout any preexisting fractures or other flaws. The fracture must be made with a "non-penetrating" fluid so that the stress distribution around the borehole is not altered by changes in the pressure of pore fluids before reaching the breakdown pressure, $P_{f}$.

Experimental difficulties may be encountered in the determination of the tensile strength, $T$, and the pore pressure, $P$. The tensile strength of rocks is a capricious quantity, depending to a large extent on the distribution of preexisting flaws in the sample tested and on the type of test used to measure it. In rocks with moderate to nigh permeability the pore pressure will come to an equilibrium with the hydrostatic head in the borehole, but if the rocks have low permeability the pore pressure is difficult to measure and the effects of drilling-induced fluctuations in pore pressure may persist for 1 ong periods of time.

Despite the stringent requirements for reliable $S_{H}$ measurements it is usually possible to find suitable sections of a borenole where relidole determinations of the greatest horizontal stress can be made. In USW-G1 we succeeded in estimating this stress from some of the fractured intervals. However, at this time we are unable to assess the accuracy of these estimates 
and additional work will be required on this problem. We will present the results of this work in a future report.

\section{Results}

The downhole pressure and flow data recorded for each nydraulic fracture conducted in USW-G1 are shown in Figure 6, and Table I summarizes tne pertinent information from the data. An unusual aspect of tilese recoras is that the least principal stresses were about the same value or lower than tile static hydrostatic water pressure in the drill pipe (see Table I and Appendix 3 ). This required some changes in our standard procedures, Dut tne metnods by which the $S_{n}$ values were chosen are both explained in the table and illustrated in Figure 6 [a discussion of standard interpretation is given in Hickman ana Zoback (1982)]. The least principal stress values are significantly lower than the vertical stress (fig. 7 ; app. 3), as expected in normal faultiny environments.

The orientations of triese drilling-induced nydraulic fractures were determined from borehole televiewer studies, and the direction of 1 east horizontal compression was found to be $N 65^{\circ} \mathrm{W} \pm 10^{\circ}$. Other stress indicators in surrounding areas indicate a $N 50^{\circ} \mathrm{W}$ direction for $S_{n}$ (see Zoback and Zoback, 1980).

\section{Drilling-Induced Fractures}

The very low magnitude of the least principal stress measured in USW-G1 explains why drilling-induced hydraulic fractures occurred. Such fractures are expected to extend and propagate when the fluid pressure in them exceeds $S_{h}$. If the pore pressure curve (fig. 7) were shifted to the right by filling the well above the ambient water table and raising downnole pressure during drilling, the fluid pressure in favorably oriented flaws or preexisting fractures would exceed $S_{n}$, and hydraulic fractures would form. Thus, the occurrence of major drilling-induced nydraulic fractures in the rock and the observation that the fluid level in the well could never be brought to the surface during drilling is best explained by the loss of drilling fluid and cuttings into the hydraulic fractures.

\section{Potential Faulting}

The low magnitude of the least horizontal principal stress, $S_{n}$, is consistent with the pattern of tectonic extension odserved in the Basin and Range province. It suggests that Yucca Mountain and the surrounding region is still, to some extent, under the influence of active tectonic forces. Tnis raises a question about the potential for active faulting in the future at the Yucca Mountain site. An approximate estimate of the stress requirea to initiate active faulting can be made by assuming that the Monr-Coulomb failure criterion is applicable and that there are suitaoly oriented fault surfaces to respond to the current state of stress. Zoback et al. (1978) showed that in normal faulting environments the stress at which frictional sliding is expected to occur is a function of the vertical stress, $S_{V}$, the coefficient of friction, $\mu$, and the pore pressure, $P_{p}$ : 

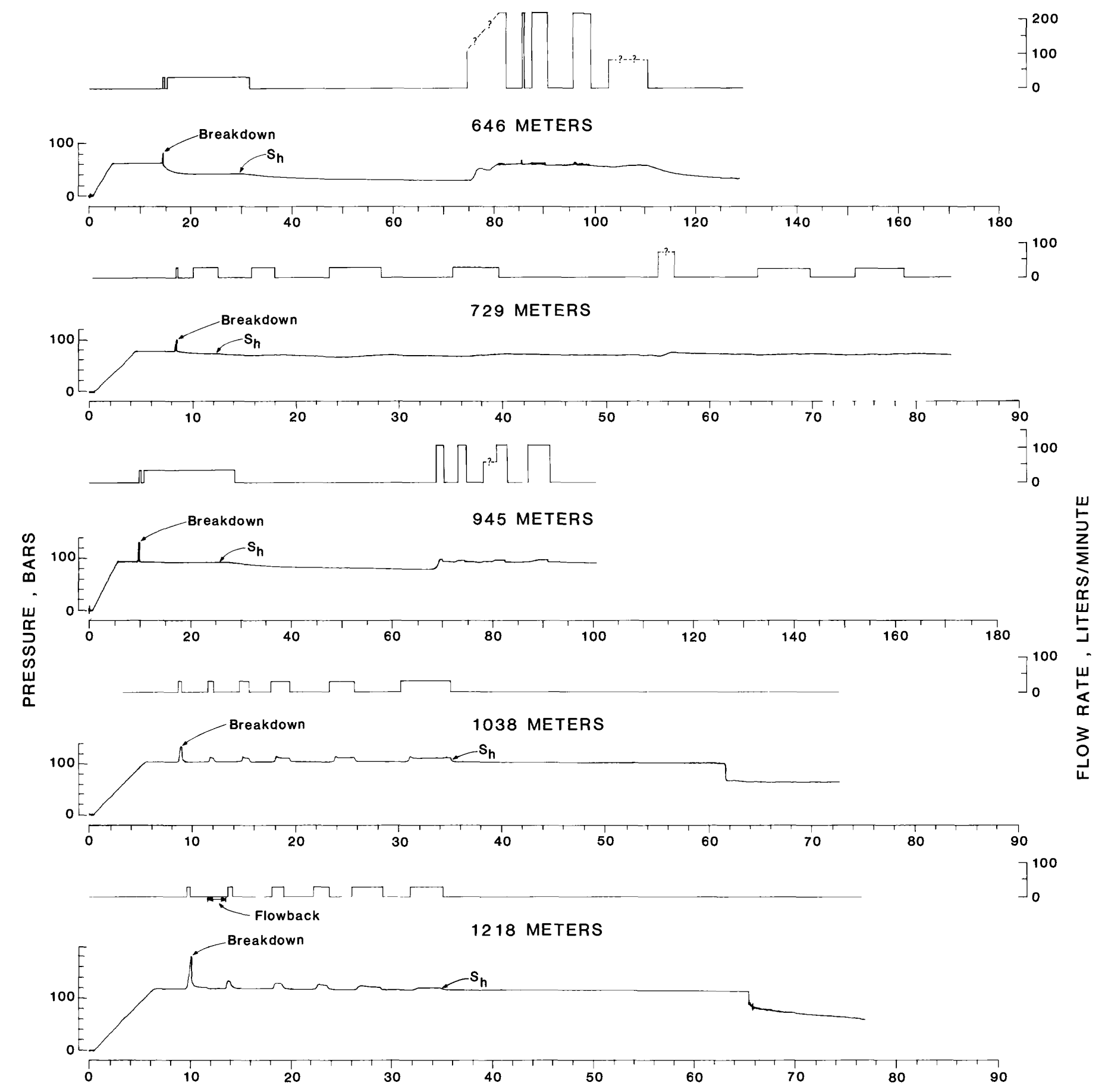

]$_{0}^{100}$

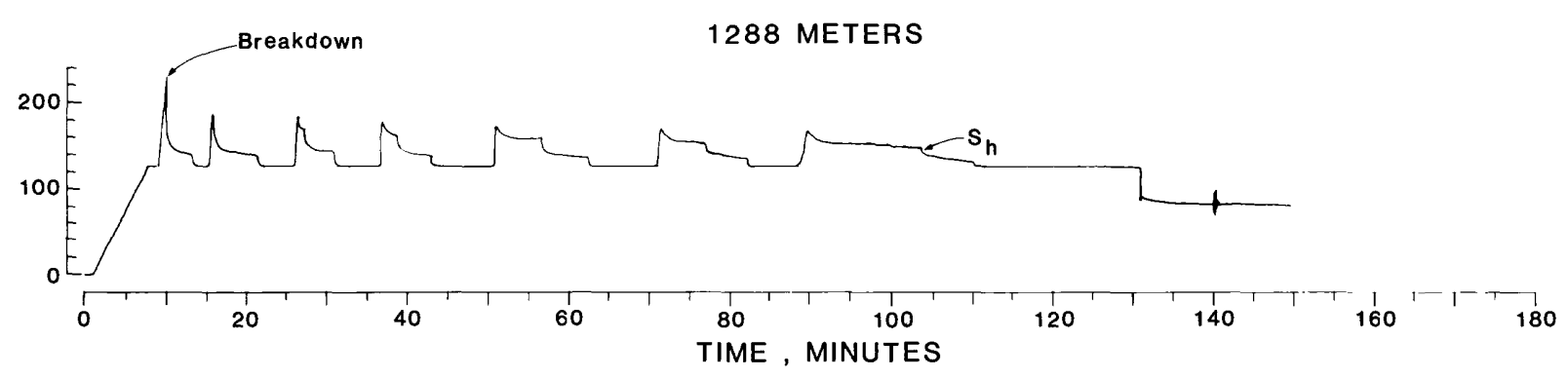

Figure 6. Downhole pressure and flow data for hydraulic fracturing stress measurements in USW-G1. Values chosen for $S_{h}$ are indicated. 
STRESS (BARS)

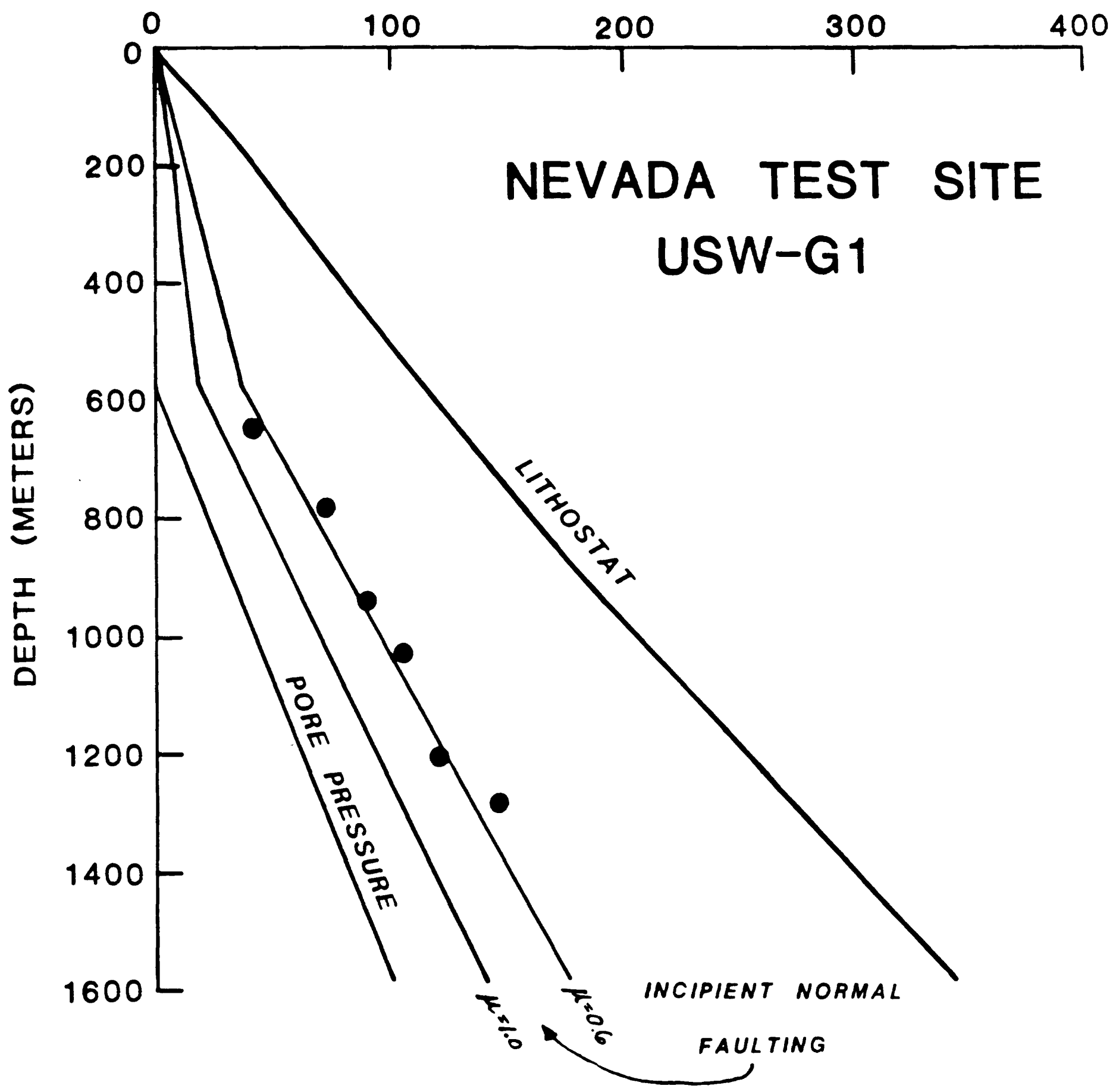

Figure 7. Least principal compressive stress, $\mathrm{S}_{\mathrm{h}}$, as a function of depth. The vertical stress (lithostat) and pore pressure at depth are shown for reference. 


$$
S_{h}=\frac{S_{v}-P p}{\left[\left(\mu^{2}+1\right)^{\frac{1}{2}}+\mu\right]^{2}}+P p
$$

This relationship assumes that there are preexisting fault surfaces witn zero cohesive strength dipping about $60^{\circ}$ and striking parallel to the direction of $\mathrm{S}_{\mathrm{H}}$.

Based on this relationship, the magnitude of $S_{n}$ at which normal faulting is expected to occur for coefficients of friction between 0.6 and 1.0 and pore pressures corresponding to a water table about $576 \mathrm{~m}$ Delow the surface is shown in Figure 7. The value for $\mu$ is reasonadle, based on the work of Byerlee (1978), and the assumed water table is approximately that observed at the well site. We conclude from the data presented in Figure 7 that the stress field as measured in USW-G1 is close to that at which failure might be expected along normal faults present in the area.

The normal faulting in the Yucca Mountain area is documented by $W$. J. Carr (written commun., 1982) and is clearly evident on the geologic map of Figure 8 . However, the absence of any seismicity on Yucca Mountain and the absence of geologic evidence for recent faulting suggest that the current stress field is not sufficient to cause failure.

A thorough investigation of the potential for rock failure on Yucca Mountain will require additional work: 1) stress measurements at additional points, 2) laboratory measurements to determine the appropriate values for the coefficient of friction of the rocks that comprise Yucca Mountain, 3) a more precise evaluation of the orientation of the stress field with respect to the orientation of existing faults, and 4 ) laboratory studies to determine if the Mohr-Coulomb failure criterion is applicable to these rocks. The presence of zeolites and other water-bearing minerals in these rocks can alter the parameters used in the criterion or the criterion itself. Despite these uncertainties, the results of this study suggest that faults on Yucca Mountain may be potentially active, and it is important to obtain more precise data on this potential and to take tnis possibility into consideration in the design of the repository. 


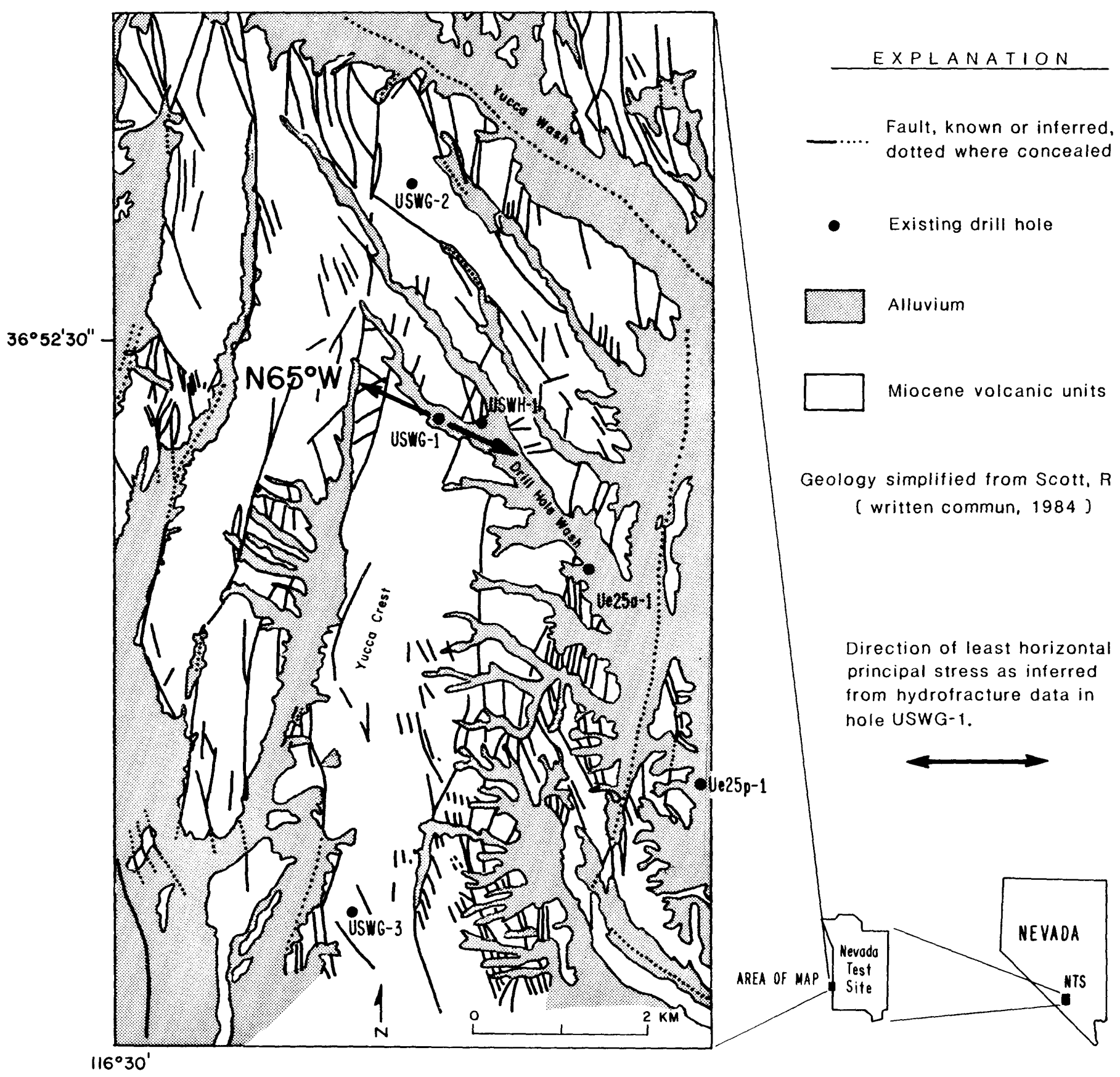

Figure 8. Geologic map of Yucca Mountain ared. 


\section{References}

Be11, J. S. and Gough, D. I., 1979, Northeast-southwest compressive stress in Alberta: Evidence from oil wells: Earth and Planetary Science Letters, v. 45, p. $475-482$.

Byerlee, J. D., 1978, Friction of rocks: Pure and Applied Geophysics, v. 116, p. $615-626$.

Hickman, S. and Zoback M. D., 1982, The interpretation of hydraulic fracturing pressure-time data for in situ stress determination: U.S. Geological Survey Open-File Report 82-1075.

Hubbert, M. K. and Willis, D. G., 1957, Mechanics of nydraulic fracturing, Journal of Petroleum Tecnnology, v. y, p. 153-168.

Snyder, D. B. and Carr, W. J., 1982, Preliminary results of gravity investigations at Yucca Mountain and vicinity, soutnern Nye County, Nevada: U.S. Geological Survey Open File Report 82-701.

Spengler, R. W., Byers, F. M.. Jr., and Warner, J. B., 1981, Stratigraphy and structure of volcanic rocks in drillhole USW-G1, Yucca Mountain, Nye County, Nevada: U.S. Geological Survey Open-File Report 81-1349.

Zemanek, J., Glenn, E. E., Norton, L. J., and Caldwe11, R. L., 1970, Formation evaluation by inspection with the borehole televiewer: Geophysics, v. 35 , no. 2 , p. 254-269.

Zoback, M. D., Healy, J. H., Roller, J. C., Gohn, G. S., and Higgins, B. B., 1978, Normal faulting and in situ stress in the South Carolina coastal plain near Charleston: Geology, v. 6, p. 147-152.

Zoback, M. D., Moos, M., and Anderson, R. N., 1982, Determination of the horizontal principal stress from wellbore breakouts (abs.): EOS, Transactions of the American Geophysical Union, v. 63, no. 45, p. 1118.

Zoback, M. L. and Zoback, M. D., 1980, State of stress in the conterninous United States: Journal of Geopnysical Research, v. 85, p. 6113-0150. 


\section{APPENDIX I}

\section{Operations}

The original planning and timing of this work were advanced to take advantage of an available drill rig and crew. The support we received was provided by REECO drilling contractors, monitored by Fenix and Scisson. The equipment and drill crews provided by the contractor for this experiment were more than satisfactory. Four drill crews were assigned to the rig permitting continuous, 24 hours/day, seven days/week operation.

Successful stress measurements by the hydrofrac method require close coordination between the scientific staff and a competent drill crew. The mode of continuous operation that was possible for these measurements was a new experience for the scientific team and required some modification of our operational procedures to make optimum use of these services. We present Delow a detailed chronology of the operation from which we draw conclusions and make recommendations for improvements in our techniques for use in planning future operations.

\section{Chronological Log of Operations}

(1981)

November 30. Conference at Las Vegas wi th Henry Melancon and Ralph Richards of DOE-WMPO. Witn their assistance we prepared a request outlining the required support.

December 13 (Sunday) 2200. Arrive at Mercury.

December 14

0930. Logging truck on site G1. Hole had been cleaned to $5328^{\prime}$ and filled with neavy mud. Two caliper logs had been run, one on $12 / 13 / 81$ to $5328^{\prime}$ and the other on 12/14/81 to $3550^{\prime}$ where the hole was blocked. Bod Calk of Fenix and Scisson provided this information.

1200. Start televiewer in hole. Hole apparently Dlocked at $2755^{\prime}$.

1430. Complete telviewer $\log$ from $2720^{\prime}$ to $2450^{\prime}$.

Set up packers.

1540. Start packer trip in.

Shift change.

2140. Packers at $2607^{\prime}$.

December 15

Start filling drill pipe with water.

0120. Kuster gauge set on circulation sleeve. Start pressure test.

0430. Start out of hole. Test failed because of blocked fiuid passage between Kuster gauge and packer mandrel.

0700. Packers out of nole. Packers had not released properly and packer assembly was damaged.

1030. Spare packer assembly did not hold pressure in surface test. ordered two new packer assemblies from Lynes, Inc.

1130. Start bit trip witnout circulation to pusn obstruction from nole if possible.

1350. Bit at $3726^{\prime}$ without hitting obvious obstructions. 
1430. Start out of hole.

1650. Bit out of hole.

1720. Start televiewer trip in hole. Encountered heavy mud at $1772^{\prime}$.

1745. Hole apparently blocked at $1852^{\prime}$.

1900. Completed televeiwer $10 \mathrm{~g}$ from $1830^{\prime}$ to $1763^{\prime}$. Quality of televiewer pictures suggested an extremely neavy mud in nole.

1920. Televiewer out of hole.

1945. Started trip in witn 3/4" OD sinker bar to test nole.

2010. Sinker bar landed at 1873'.

2100. Requested contractor to replace mud with a less viscous filuid. December 16. Requested Fenix and Scisson to replace mud in hole with 30 viscosity mud.

We reasoned that the apparent blocks were not due to hole failure but to excessive mud viscosity. The nole nad been filled with nominal 30 viscosity mud but mud samples recovered on logging tools were extremely viscous, suggesting that mud properties were changing in the hole and viscosity was increasing with time.

1007. Began replacement of mud with new mud with measured 30-35 viscosity (BOD Calk).

December 17

1930. At 2000'.

0200. Completed change of mud to $4027^{\prime}$.

0245. Start trip in with televiewer. Encountered fluid at 1370'.

0320. Televiewer landed at 4370'. No return signal below $4350^{\prime}$.

0350. Start televiewer log up at 4350'.

1700. Reach water table at $1480^{\prime}$. Complete televiewer log from $4350^{\prime}$ to $1480^{\prime}$.

1930. New packers on rig floor. Start packer trip in to $4000^{\prime}$. December 18

2300. Packers at $4000^{\prime}$.

0100. Run wireline to check packer depth. Packers at $3997^{\prime}$.

0345. Set packers.

0400. Trip in sinker bar to open circulation sleeve. Start frac.

1200. Complete testing at 4000'. Packers unset and tripping out.

1230. Dress packers.

1410. Start packer trip in to $3400^{\prime}$.

1600. Packers at $3405^{\prime}$.

1620. Start sinker dar trip in.

1740. Sinker bar set on circulation sleeve at 3478'. Adjusted packers to correct depth.

1836. Start filling pipe with water.

2020. Pipe full.

2038. Start sinker bar trip in hole.

2053. Knock down at $3406^{\prime}$.

2131. Kuster gauge set on circulation sleeve.

2139. Frac good at $3406^{\prime}$.

December 19

2250. Packers unset and tripping out.

0130. Dress packers.

0300. Start packer trip in hole.

0530. Packers at 2600'. 
0730. Start sinker Dar trip in.

Drillers' depth 2594.18'.

Wireline deptn 2601'.

0900. Sinker bar out. Lift pipe 5'.

Corrected depth 25y6'.

0940. Start filling pipe with water.

1014. Pipe ful1.

1040. Set packers. Fix pressure sub 1eak.

1103. Start sinker bar trip in.

1135. Knock down.

1201. Kuster gauge set on circulation sleeve.

1208. Frac.

1324. Unset packers.

1343. Start packer trip out of hole.

1500. Dress packers and test.

1600. Start in hole.

1815. Check depth to packers.

1920. Packers at $3099^{\prime}$.

Fill pipe with water.

2050. Packers inflated.

2057. Start sinker bar trip in.

2120. Knock down.

2155. Kuster gauge with three-hour clock set on circulation sleeve.

2204. Frac.

2240. Set up rig for pump test.

2300. Start pump test with rig pump. USGS frac pump could not pump fast enough to raise downhole pressure.

December 20

0045. Finish pump test.

0115. Unset $J$ valve and packers. Start packer trip out.

0330-0430. Dress packers.

0500. Start packer trip in.

0600. Packers at about $2130^{\prime}$.

0655. Circulation sleeve depth $2162.3^{\prime}$, which is $32^{\prime}$ too deep. Pull two joints, $42.5^{\prime}$.

0740. Circulation sleeve depth at $2121^{\prime}$, and filling pipe.

0815. Pipe topped off with water.

0833. Inflate packers (565 psi).

0900. Knock down circulation sleeve.

1002. Frac (650 psi).

1100. Continue test with $5 \times 8$ skid mud pump.

1201. End test.

1229. Unset J 1 atch.

1232. Unset packers and start packer trip out.

1330. Packers out.

1500. Start televiewer trip in for post-frac televiewer $10 \mathrm{~g}$.

December 21

2200. Finish post-frac televiewer log.

0030. Start packer trip in.

0300. Complete packer run to $4225^{\prime}$.

0430. Start sinker bar trip in.

0455. Interrupt sinker bar trip in at $3700^{\prime}$ and pump $100 \mathrm{gd}$ l. fresh water into pipe. 
0500. Continue sinker Dar trip in.

0526. Circulation sleeve at 4257.5'.

0614. Raise pipe $2^{\prime}$.

0700. Start filling pipe.

0y00. Pipe full.

0942. Inflate packers to 505 psi.

1020. Knock down.

1132. Kuster gauge set on circulation sleeve.

1145. (Approx.) Crew change.

1144-1330. Frac at about 800 psi.

Pump tests at about 800 psi.

1350. Unset J latch and packers.

1540. Crew change.

1800. Packers tripped out of nole.

Pack up equipment.

2030. Arrive at Mercury.

Based on the experience described above we draw the following conclusions. Preparation of the nole using a drilling mud of moderate viscosity is required for the success of televiewer logging. In the 4-in-diameter USW-G1 hole mud with a measured viscosity between 30 and 35 was satisfactory. The mud viscosity should be measured at the site before injection into the borehole. Following the cleaning and preparation of the nole, a caliper log is desiravle to detect any blocks in the hole that would tear the packers during the stress medsurements.

After the hole is suitably conditioned the televiewer logging requires about 24 hours for a $5,000 \mathrm{ft}$ hole. It is usually most efficient to complete this $\log$ in one continuous run al though it can be distributed over time, interspersed with stress measurements. The televiewer is still an experimental instrument and breakdowns are not unusual. Any breakdowns at this point can be very expensive because they stop the program until repairs can be completed. In holes where the televiewer can be run without replacing the drilling mud or clearing blocked sections it is advisable to complete the televiewer logging before the drilling rig is engaged. Where this is not possible it seems advisable, though expensive, to have two televiewer systems on site to decrease the likelinood of delays due to televiewer malfunction.

There are several methods for lowering and operating a stradale packer system in a drill hole, and each method nas advantages and disadvantages. The U.S. Geological Survey has selected a metnod that is optimum for our purposes and we are concentrating our efforts on improvements in this one approach, but a brief discussion of diternative approacnes and our reasons for nơt using tnem may be useful.

Packers can be lowered on flexible high-pressure nose from a winch or several winches with a combination of hoses and wires. In clean holes less than about $500 \mathrm{~m}$ in depth this is an ideal approach. It eliminates the need for a drilling rig and offers maximum control of the packer system. When the system is working without problems, many measurements can be made in a few days. The disadvantages of tnis approach arise in prodiem noles and in the depth limitations of the system. One small rock can jam a packer and when a system is stuck there are very few options for freeing it. If one wishes to 
go to greater deptn large winches are required to nold the tuoing and caoles needed to operate the system at the higher pressures, and it becomes more difficult to keep the tubes and cables from tangling as they are orougnt out of the hole.

A second approach involves tying flexible tubing and wireline to the outside of drill pipe as the packers are lowered into position. This system offers the advantages of control and flexibility and offers a better chance of retrieving a stuck packer system. When the nole is clean, measurements can de made quickly with this system; however, the external cables and tubing are often damaged when moving the system into the hole, and the ultimate disaster of having 5,000 or 6,000 ft of tubing twisted around the drill steel and packers stuck in the hole is always a possibility.

The design of the USGS system is based on two objectives. First, we wish to avoid leaving a collage of stuck packers and wirelines when the experiment is finished. Second, the basic system should not have 1 imitations in depth or hole size. The system, at present, trades speed and some flexibility in control of packer pressures in order to meet these goals. The central disadvantage of the USGS system is the necessity of making separate pipe trips for each stress measurement. We hope that a new resettable packer system, which is not yet complete, will remove this requirement. follows:

The main steps in the stress measurement procedure can be summarized as

1. Select fracture intervals from the televiewer log. This task should be completed for all intervals before beginning the test and requires doout 24 nours.

2. Prepare a set of packers for the stress measurement. About tnree hours are required to clean the packer systems, replace damaged 0 rings, cneck valves, and test the packer systems under pressure to assure reliable operation downhole.

3. Lower packers to desired depth in the hole. A moderately efficient drill crew can add a $60 \mathrm{ft}$ stand of pipe in about 90 seconds. We estimate adout yu minutes for a 3,000 ft measurement.

4. Run the logging cable to check the deptn of the packer. The logging cable runs into the hole at about $250 \mathrm{ft} / \mathrm{min}$ and out of the hole at about $100 \mathrm{ft} / \mathrm{min}$. It takes about 20 minutes to run in, including the set up time, and about 30 minutes to come out, giving 50 minutes for this depth check.

5. Adjust the depth of packers if necessary; requires about 15 minutes.

6. Fill the pipe with clean water. This is an important step because it gives a clean fluid with known density to set the packers and produce fracs. This process is time consuming as air is trapped in the pipe during filling, limiting the fill rate and necessitating occassional interruptions while the air is vented. Pipe fill time requires approximately 90 minutes and varies with frac depth and tubing size. 
7. Connect the pressure system to the top of the drill pipe; set the packers and calibrate pressure gauges.

8. Remove the pressure head and run the sinker bar down on the wireline to open the circulation valve. The drill pipe is now open to the fracture interval. The sinker bar is recovered, the Kuster pressure recorder lowered to the packers, and the surface pressure system reconnected; 1 nour.

9. Run the sequence of frac tests; 90 minutes.

10. Pull packers from the hole; 90 minutes.

To summarize the above steps:

\begin{tabular}{ll} 
1. Select fracture intervals & 24 nrs for all fracs \\
\hline 2. Prepare packers & 180 minutes \\
3. Lower packers & 90 \\
4. Check depth & 50 \\
5. Adjust deptn & 15 \\
6. Fill pipe & 90 \\
7. Set packers & 60 \\
8. Knockdown & 60 \\
9. Frac & 90 \\
10. Recover packers & $\frac{90}{725}$ minutes $=12$ nours and 5 min.
\end{tabular}

At this rate two stress measurements per day are theoretically possible. Allowing two days for televiewer measurement, it should have been possible to make measurements at 12 deptns in the borehole in the time available. Six measurements were completed, which we consider satisfactory for this first attempt. Time was required to instruct the drill crews and some time was lost waiting for delivery of replacement parts for the damaged packers. We did not fully appreciate the difficuities involved in a 24-nour operation and the scientific staff was not prepared to take full advantage of this service. Considering the cost of rig time in this operation, it is clearly desirable to work on our procedures and attempt to increase the efficiency of the operation. Much of the lost time can be saved by close attention to details and advanced preparation.

I tems :

1. A spare televiewer system should be on site to minimize delays related to televiewer breakdown.

2. At least three complete packer systems should be available at the start of operations with one system always clean and ready to go in the nole. Looking at the time directly related to the stress measurements we see that 
only three out of the 12 hours were spent lowering the packers and removing them from the hole. A good crew, using a drill equipped with power tongs and pipe racking, can perform this part of the operation very effectively. Une and a half hours were spent cleaning packers. If spare systems are available this task can be carried out with the aid of the drill crew during the frac tests, reducing lost rig time.

3. Accurate pipe tallies and attention to the pipe count can improve the accuracy of the depth estimation and save time relating to depth errors.

4-8. Items 4 through 8 are interrelated. Together they required 235 minutes. Ideally, these tasks should be completed in 90 minutes. There are subtle difficulties related to these activities that have frustrated our previous attempts to reduce this time. For example, in principle tne most accurate measure of depth in a drill hole is given by the drill steel or tubing, providing a good pipe tally is maintained and care is taken to maintain the order and counting of pipe stands as they are tripped in the hole. In our experience we have not always been able to rely on the depth measurement from drill crews, and we have not been able to eliminate the time required to check the depth before setting the packers.

Another task that has frustrated our attempts to reduce rig time is filling the pipe with water. This is a slow process because the entrapped air creates a geyser-like action and blows some of the water back out of the pipe if one attempts to speed the process.

In our next operation we will try to modify our system so that some of these steps can be combined. We plan to use a lubricator that will seal the wireline at the surface. This procedure will permit us to combine the depth check with packer inflation and the opening of the knockdown valve.

We envision an ideal operating schedule as follows:

0:00 Start packer trip in nole.

1:30 Packers down. Run wireline.

2:00* Wireline down. Check aepth. Start filling pipe.

3:00 Set packers. Calibrate.

3:30 Knockdown circulation valve. Pull wireline.

4:00 Set Kuster gauge. Start frac.

5:30 Frac complete. Pull packers.

6:30 Packers out.

*Dri11 crew prepare packers for next run.

With this schedule we can theoretically make three fracture measurements in a 24-hour period, which would be a satisfactory efficiency for experiments on Yucca Mountain. 
The problem of fracture orientation has not been discussed in detail as it was not a problem at the Yucca Mountain site. Fracture orientation is usually a time consuming operation, but in the USW-G1 hole the rocks had been extensively hydrofractured during the drilling operation, and large vertical fractures were observed on the original televiewer log which gave us an accurate measurement of the stress orientation. Other sites on Yucca Mountain may not show such clear features and orientations must be determined as follows. After completion of a set of hydrofrac tests a televiewer log is repeated over the fractured intervals and it may be possible by comparing pre- and posthydrofrac televiewer records to locate the fracture that was produced by the stress test. However, the fractures produced for stress measurements often do not develop well enough to be seen on the post-hydrofrac televiewer log. In these cases an impression packer, wrapped with uncured rubber material, is used to record the fractures. When the packer is inflated over a fracture interval, the fracture is reopened and the soft rubber is forced in, thereby leaving an impression. This procedure requires about the same amount of time as the initial nydrofrac measurement and is of ten limited to fewer measurements of direction than is desirable. An obvious solution to this problem is the development of a system to prop open the fractures following the completion of the nyarofrac test. So far our attempts to do this have not been satisfactory. Too little propant results in failure to prop open the fracture enougn to ve apparent on the televiewer records, and too much propant may plug the packer system or deposit material on top of the packers. The latter case may cause a packer to get stuck in the borehole. We are presently exploring methods to obtain more consistent televiewer orientations. 


\section{APPENDIX II}

Televiewer Logs of Hole USW-G1

(Depths in feet) 

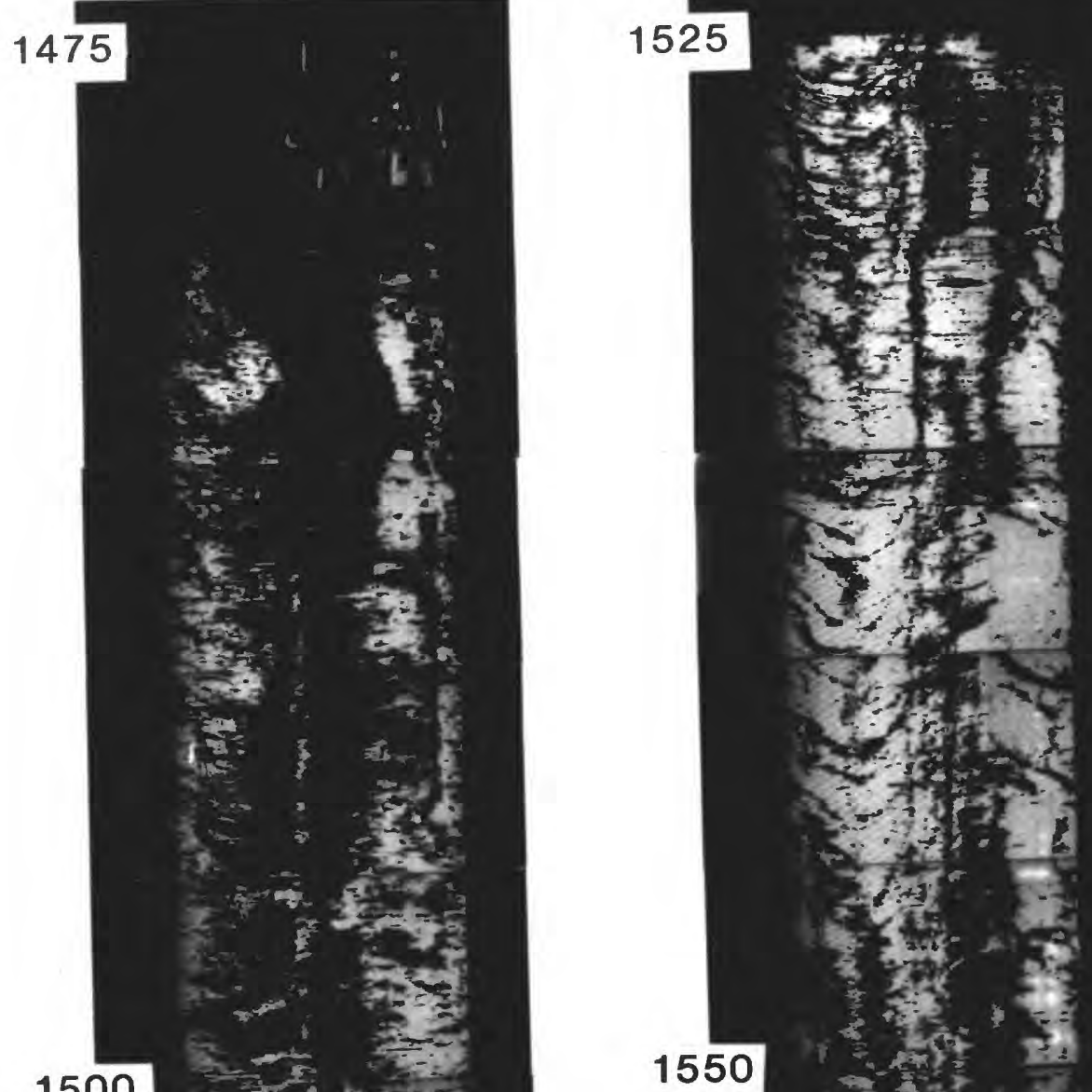

1575
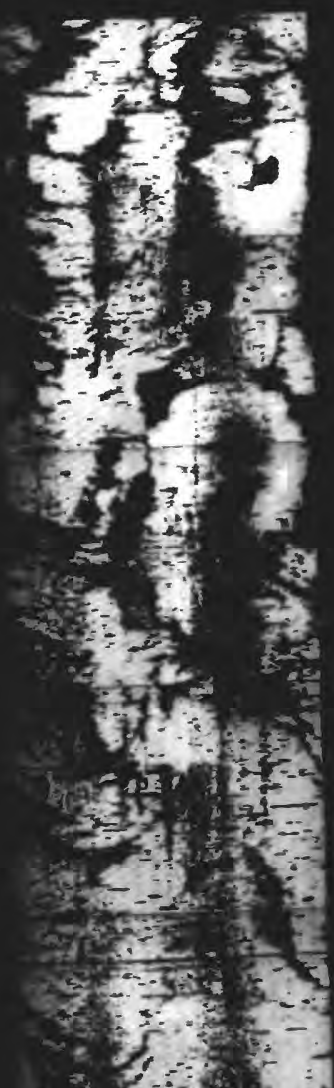

1500

ind by

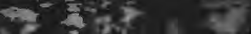

$x_{0}-x^{2}+t^{2}-1$

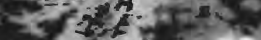

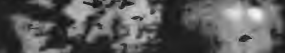

난 3

in: 25

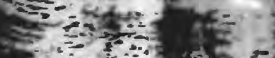

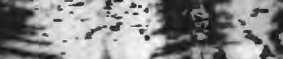

$x=2-23 ?$

$2+203$, है:

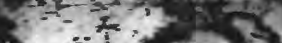

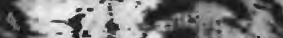

- is $8 \mathrm{y}$

$2-2-\frac{1}{4}$.

$=2-15=$ $32 .+205$

T. $=2 x^{2}-5$

$4=0+-1$

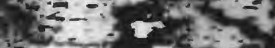

$7 x+2=-2 x+3$

$x=6,3=$

1. -7. of

$34-6,5$

$42-10$

$x^{2}, 2,0=1$ sot 2

$-2 x^{2}+3^{2}:-$ Tex 1

1525

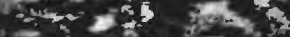

कर

1575

-xyser

1600
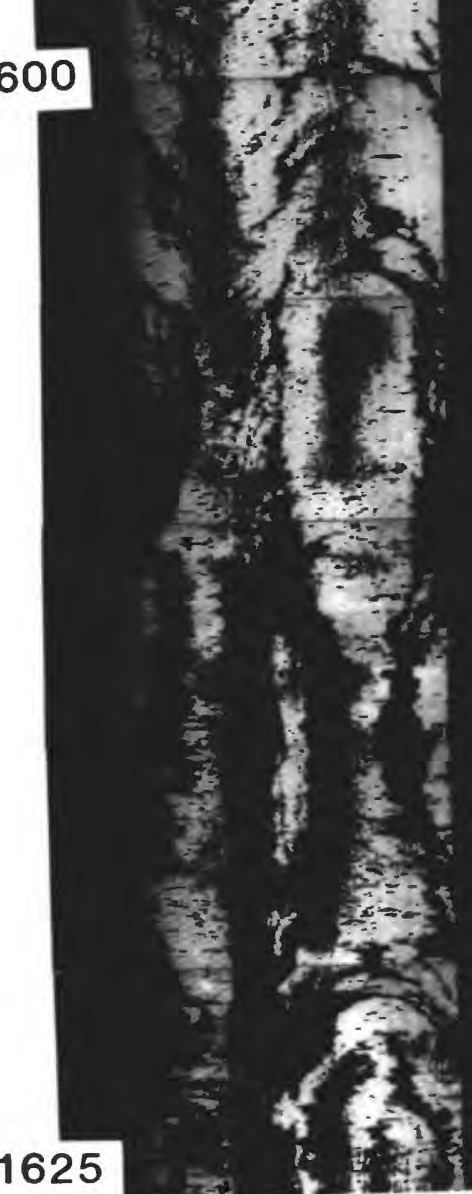


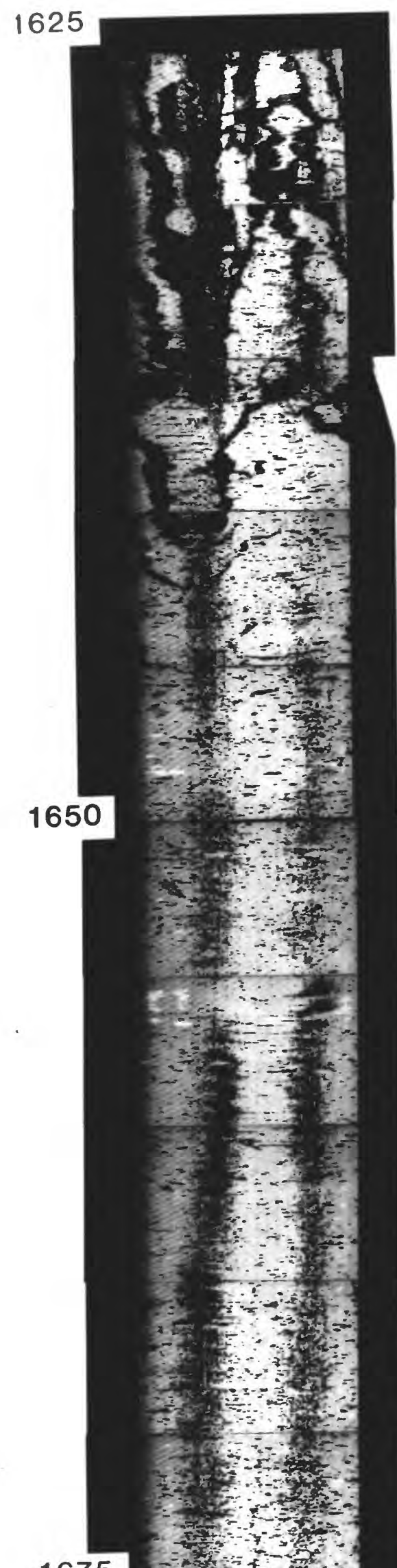

$1675=-15$
1675

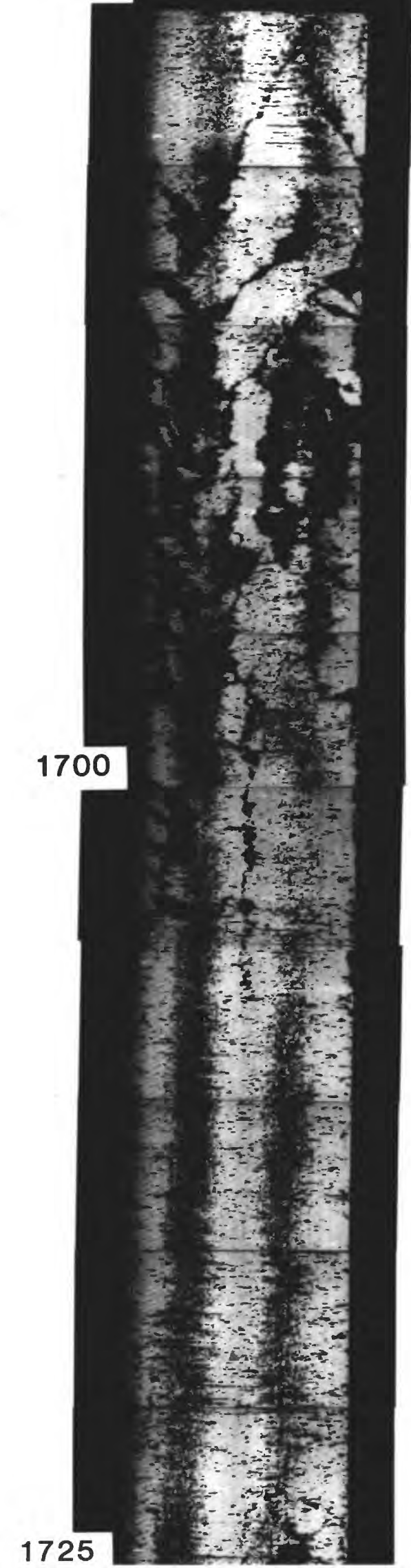

$2 \%$
1725

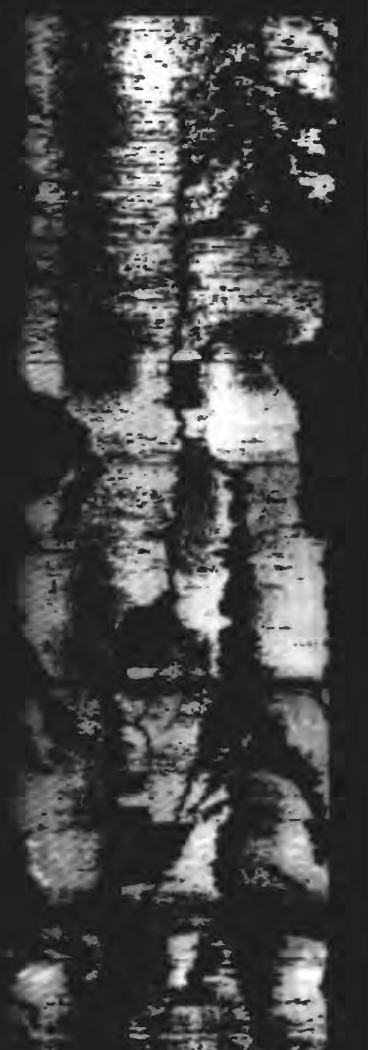

1750
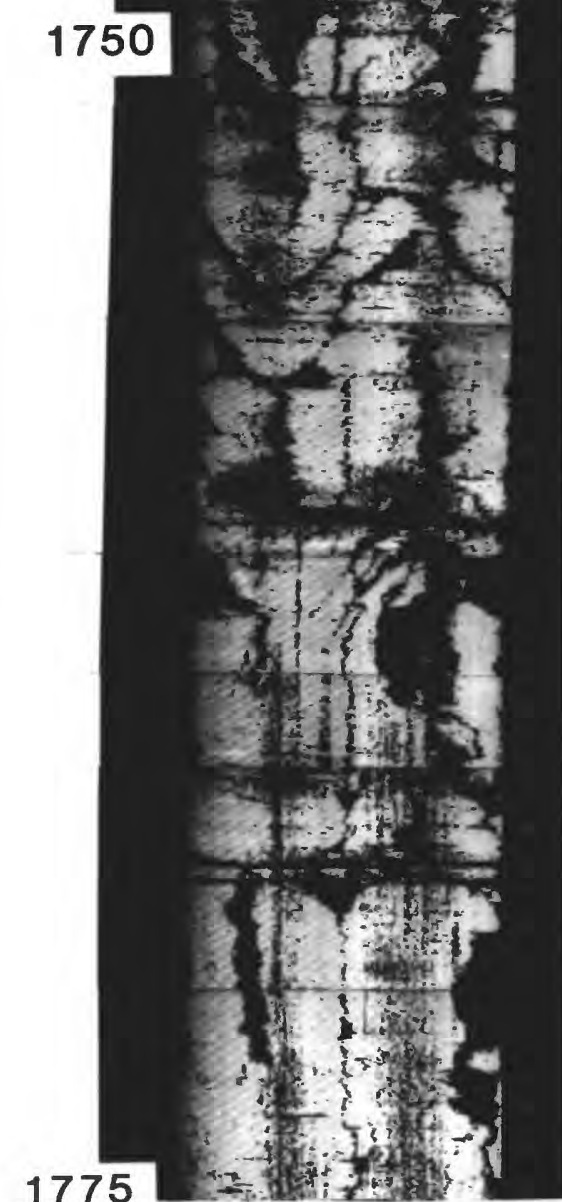


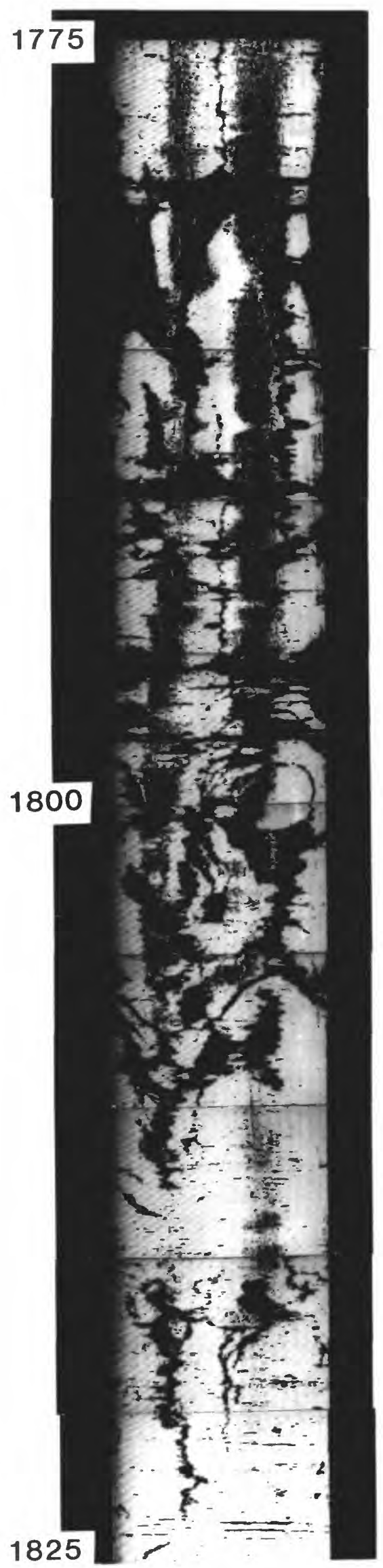

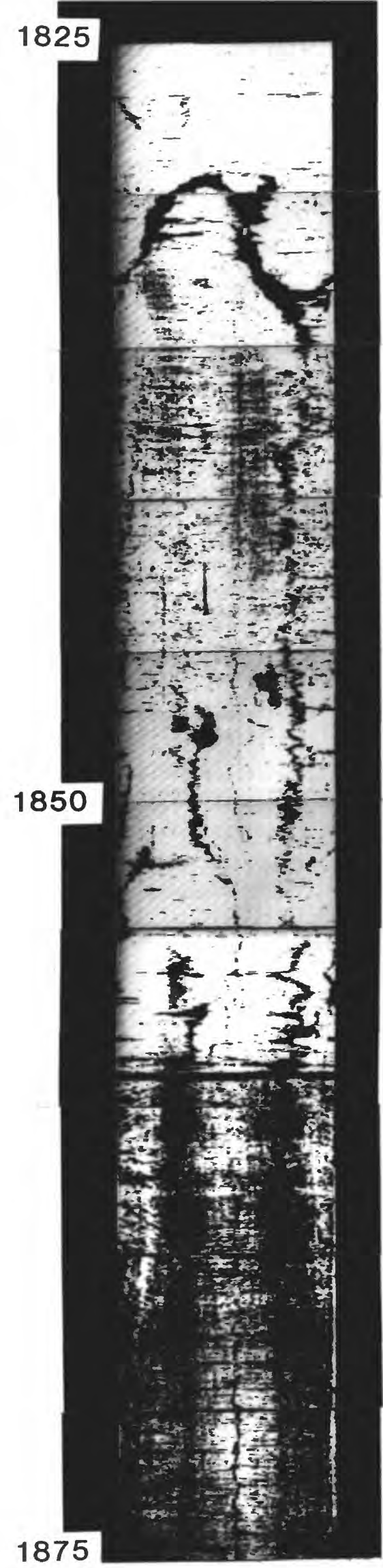

1875

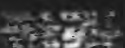

incte

-3 .

$\lim _{1}$

chat

$+\frac{2 x}{20}$

s?

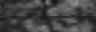

axtion

a)

라 तो

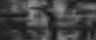

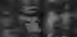

xas

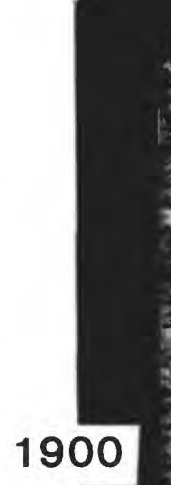

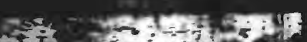

$40=2$ ?

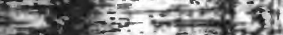

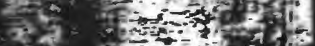

त) $4 \div$

$405-45-13$

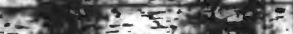

$-1 \quad-734$

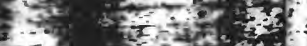

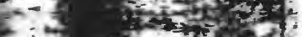

-3 intar

$-120010$

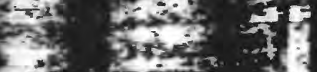

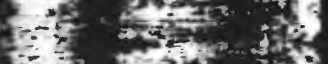

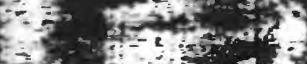

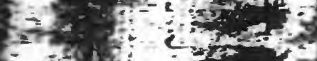

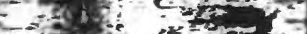

$=2 x+2+2$

$0 x^{2}-2=x$

37 ine

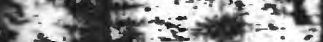

$3+70=1 ;$

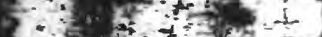

$\therefore$ - $e_{2}=2 x^{2}$

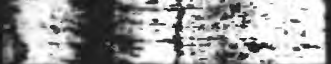

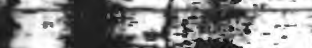

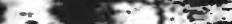

$y=1+x+5=$

$=5.504$

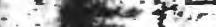

- $3 \sin ^{2}$

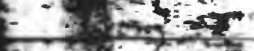

sed $7 \cdot \rightarrow$

$-x+3$

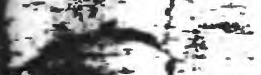

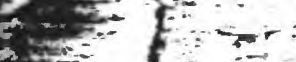

mesco

$60-5=-1$

$\rightarrow 25$ से

$=+5=$

trit

tar $=2$

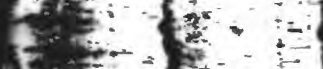

1925

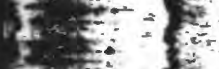



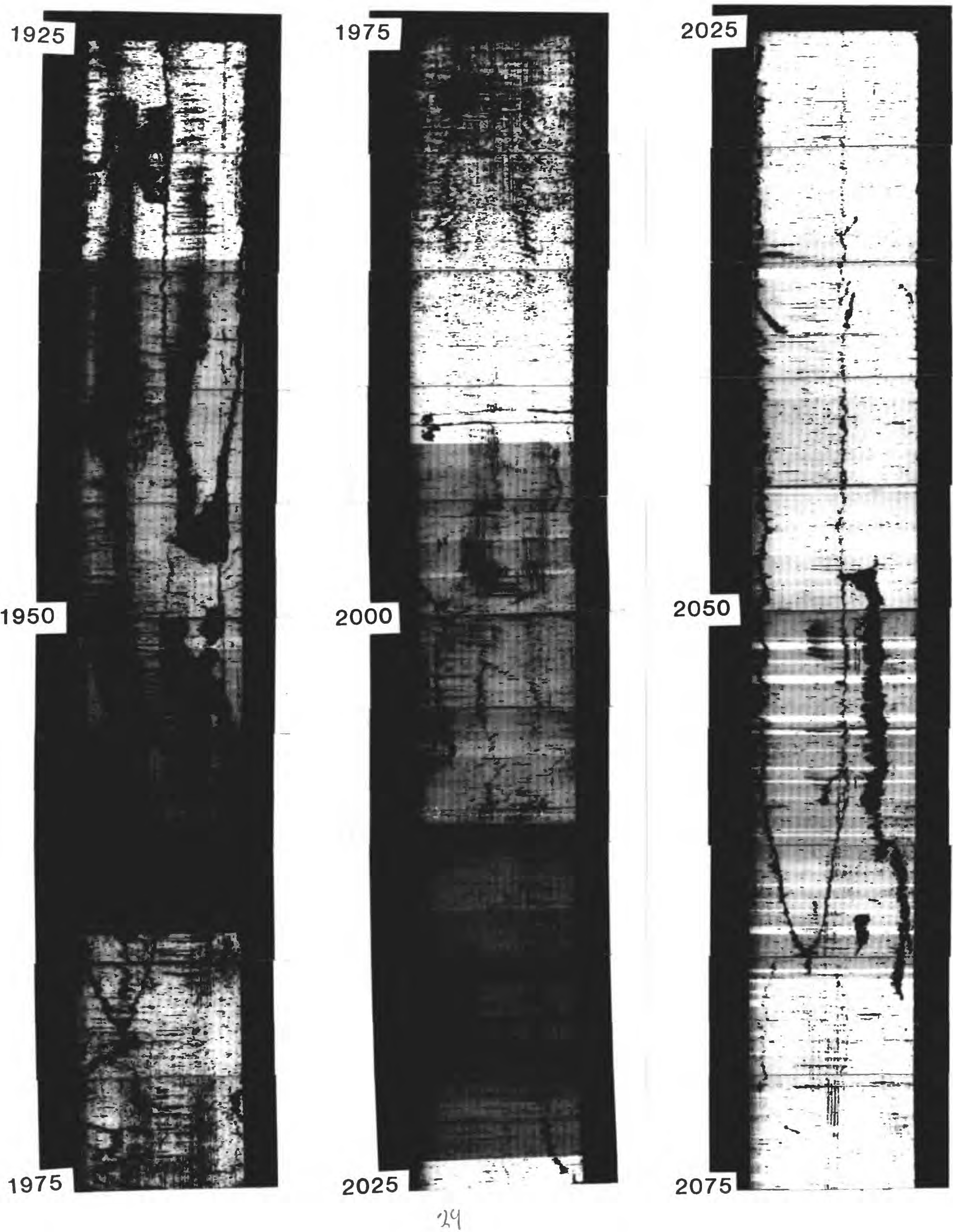

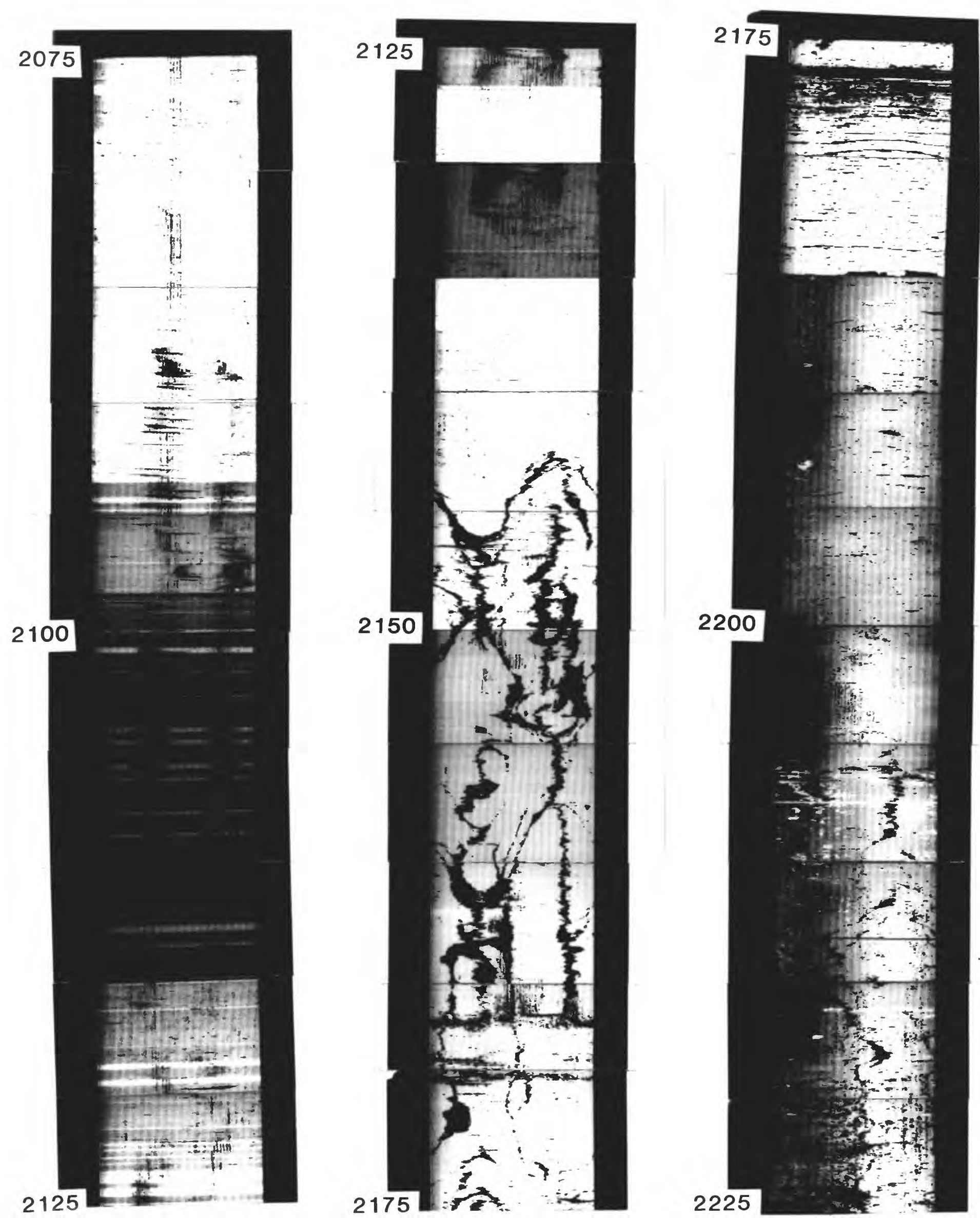


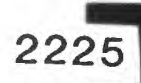

2250

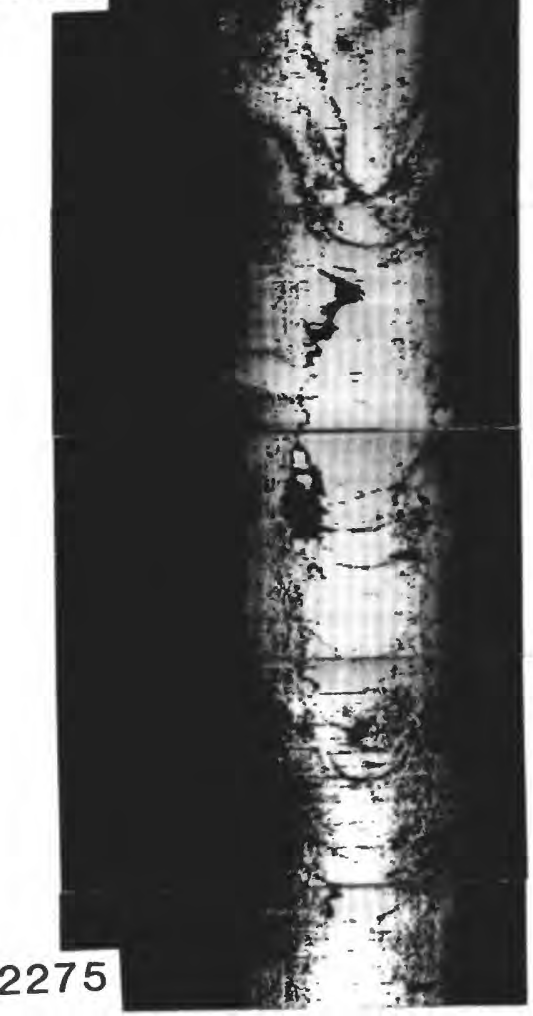

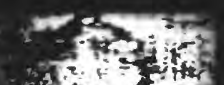

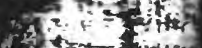

$x+\frac{1}{2}+4$

as $=51$

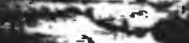

政:

सreet

,

$-73$

- is

a)

$\rightarrow$ it:

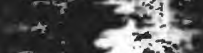

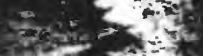

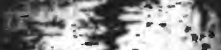

an $\Rightarrow=0$

$x^{2}=2+3$

in

(b)

दू - की

S.

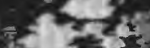

लोरी

$\Rightarrow$

$x-\mathrm{C}^{2}$

if

$y=2$

त:

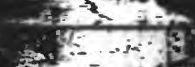

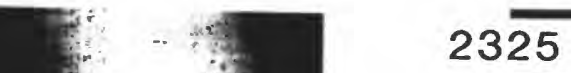

2325

2300

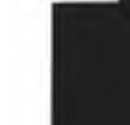

2350

站

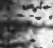

as:

(2)

-

A. -2

2. 3

t:

$x=-4$

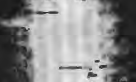

6. $\frac{2}{2}$

$\xi_{-1}$

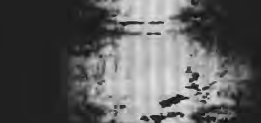

에.

-

है? 7

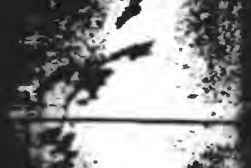

is.

16

gin

net

i.s.

$+\frac{2}{3}$

A, $10,-1$

32:

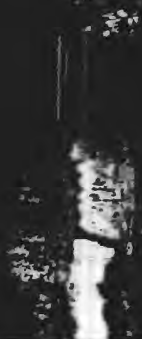

2325

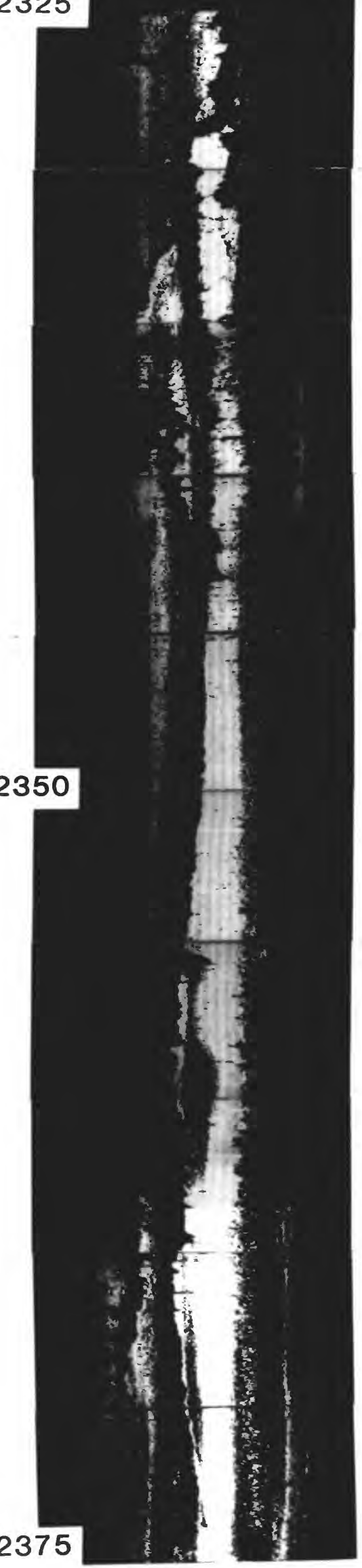

31 

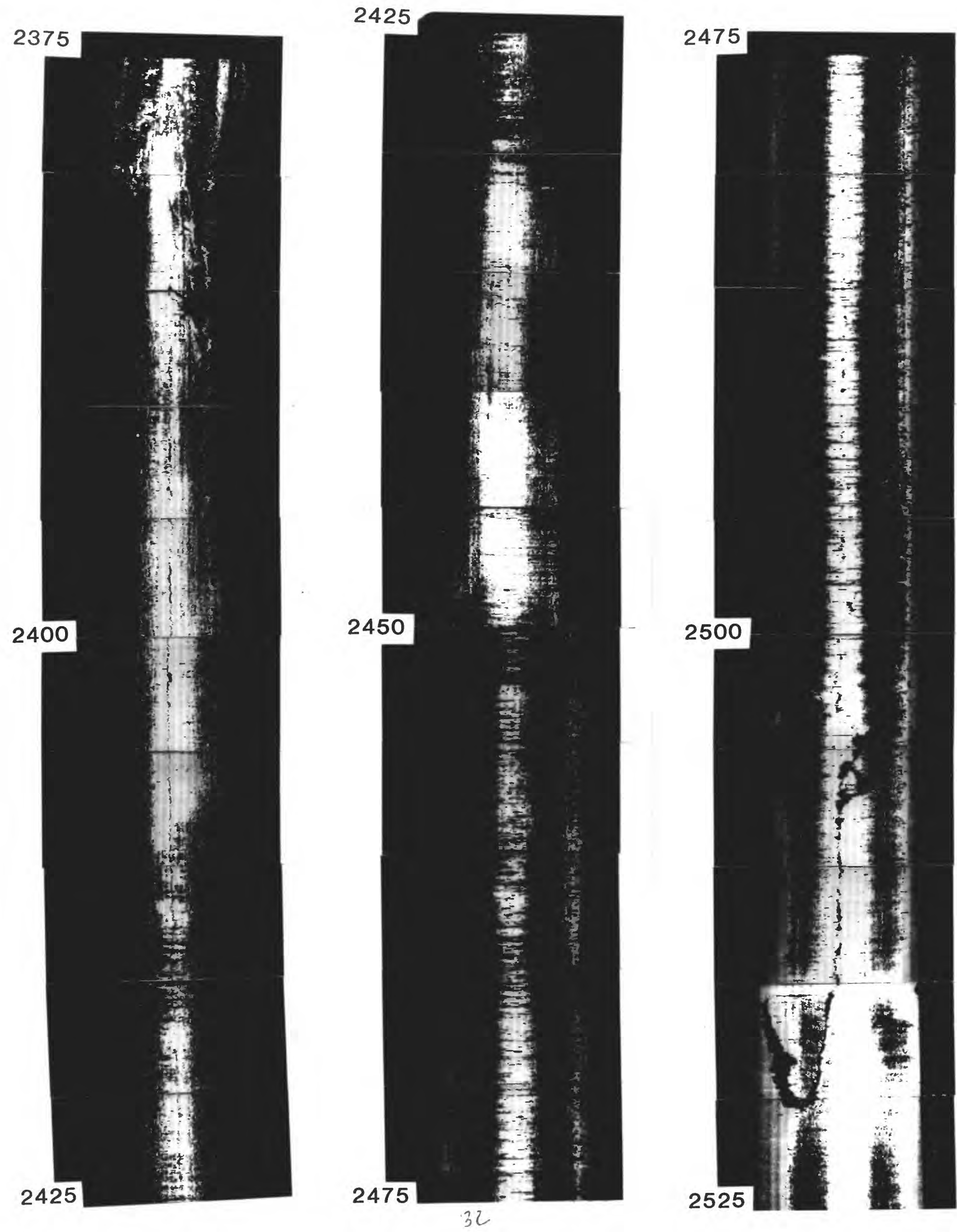


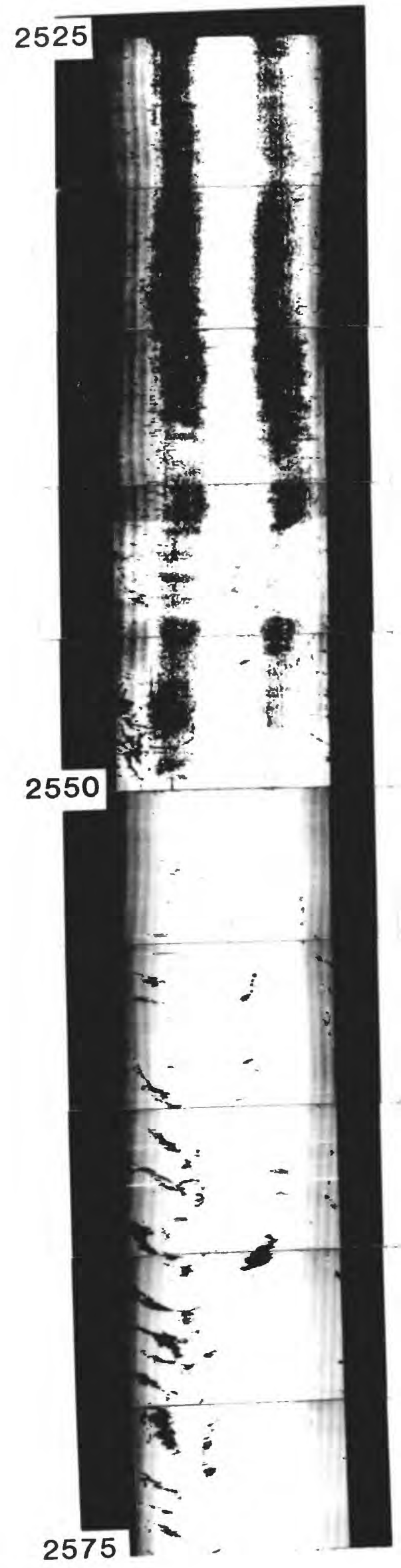

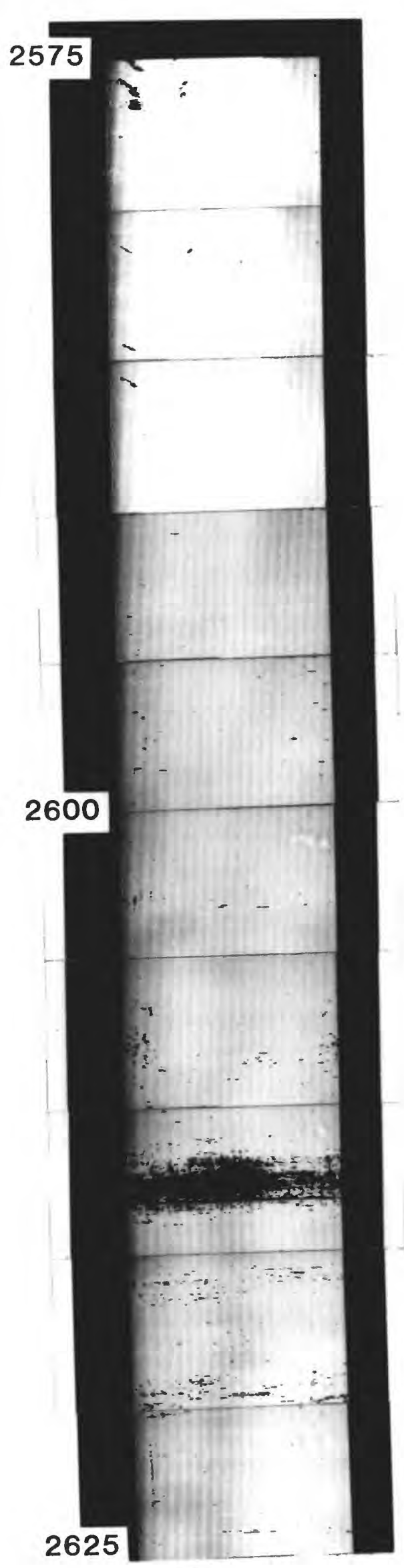

33
2625
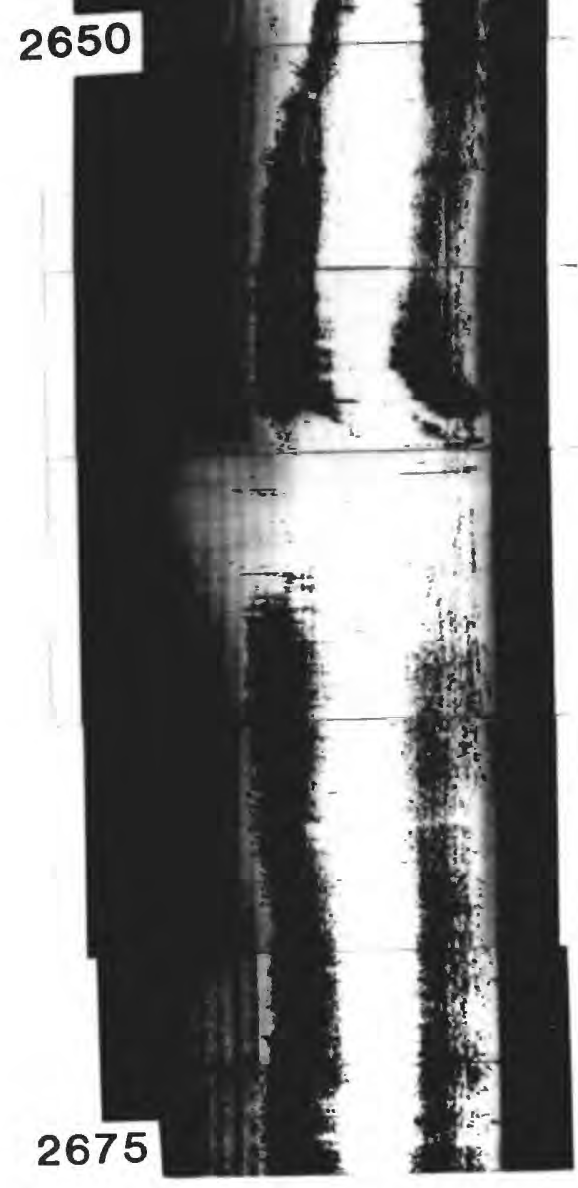

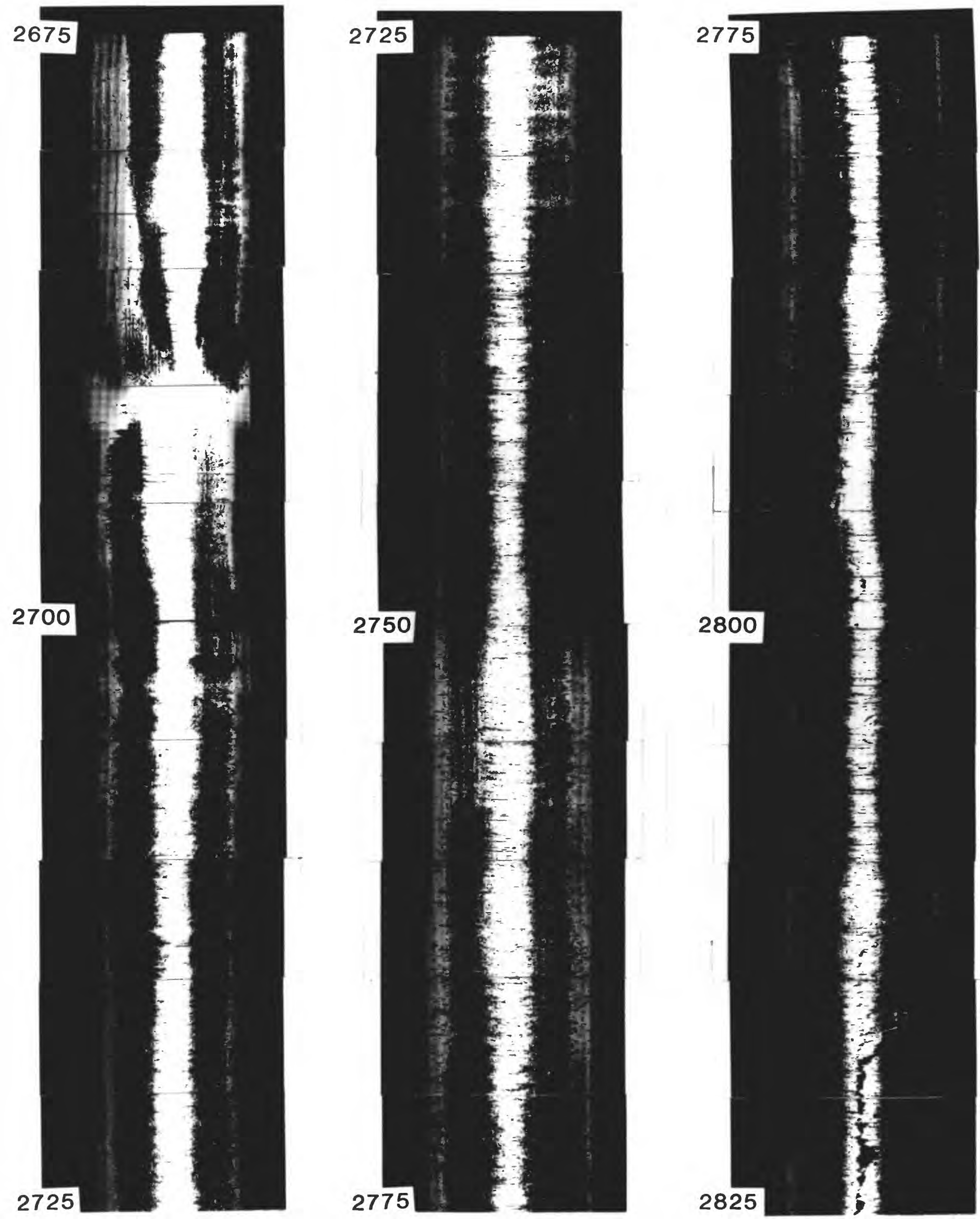

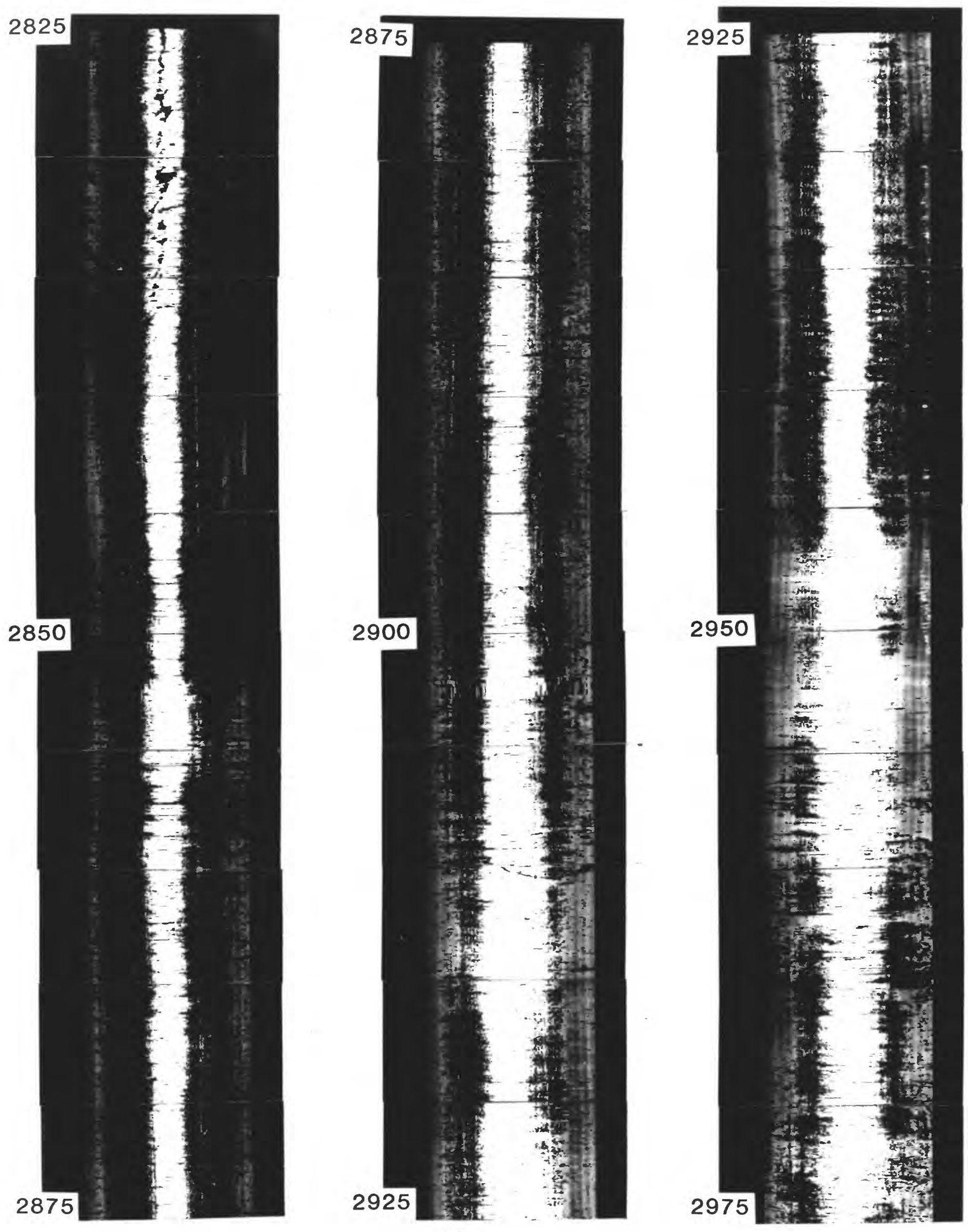

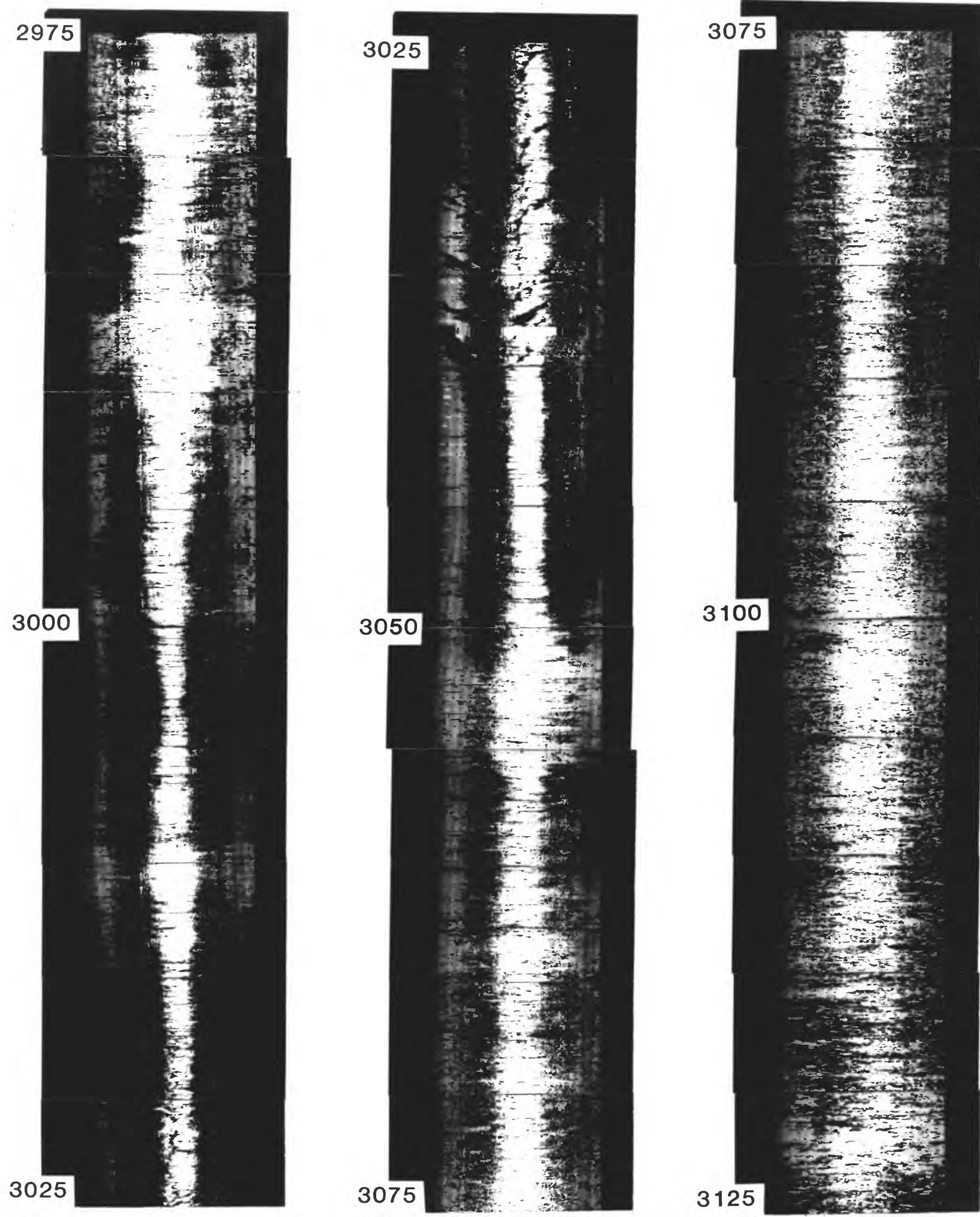

3 

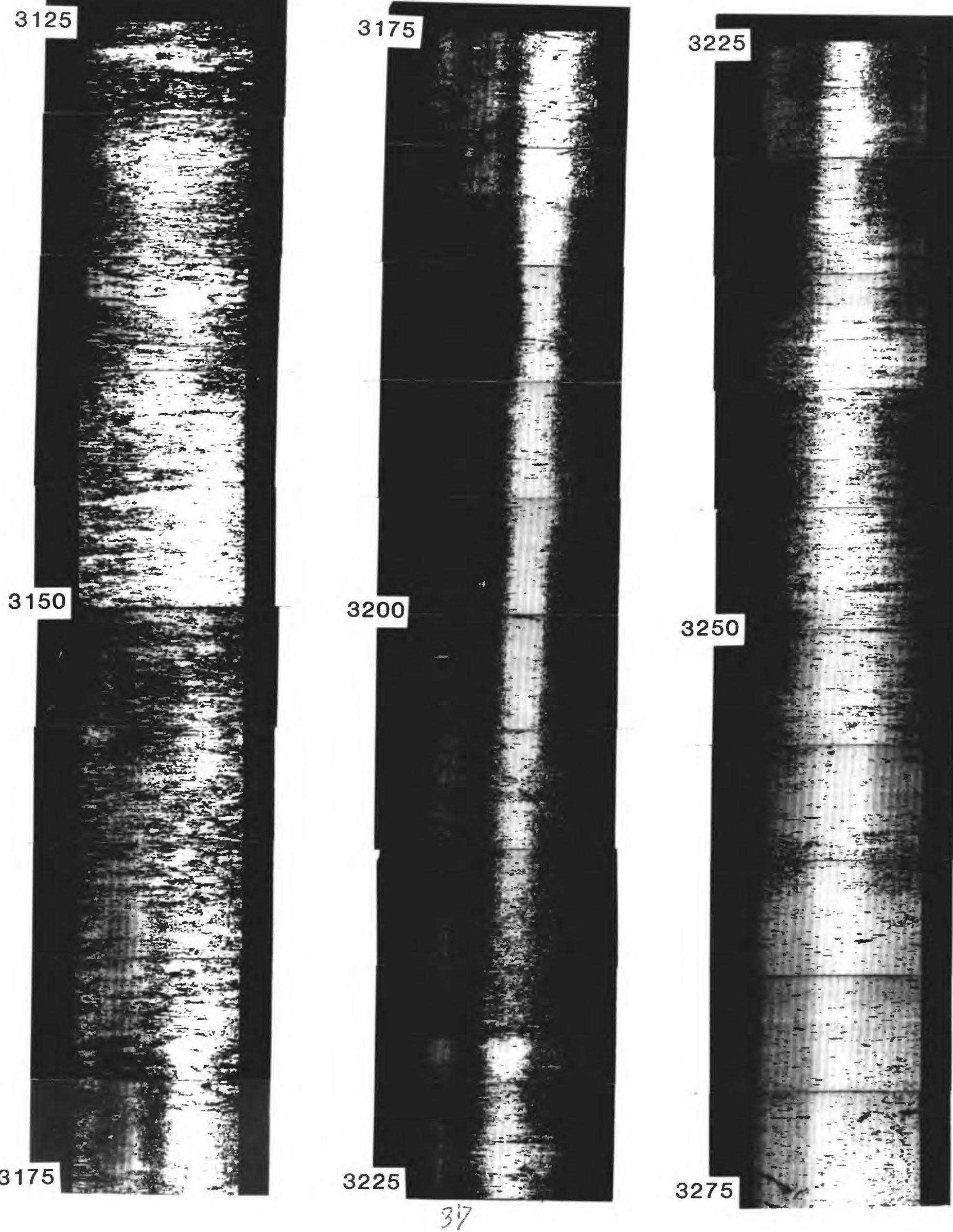


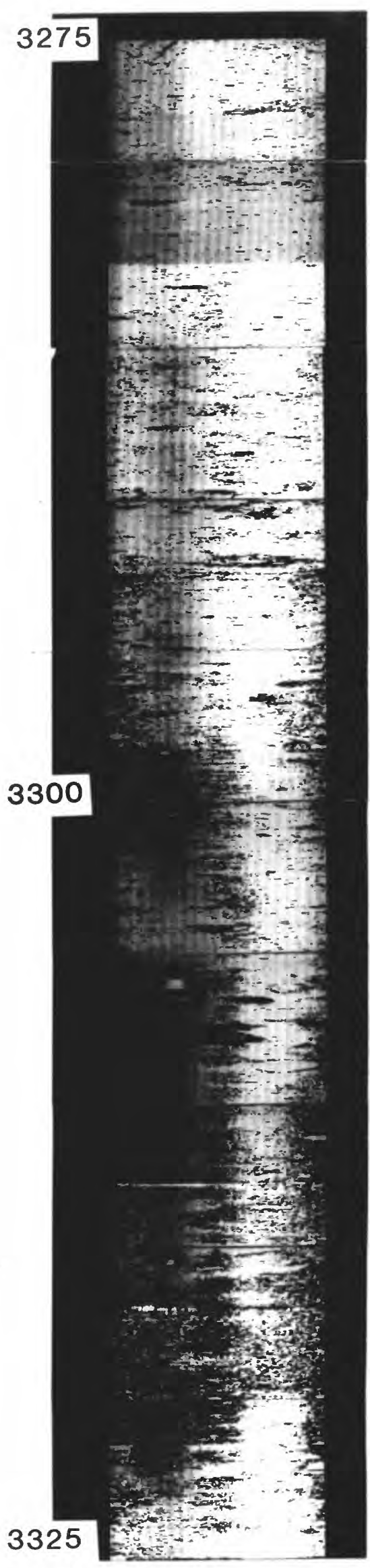

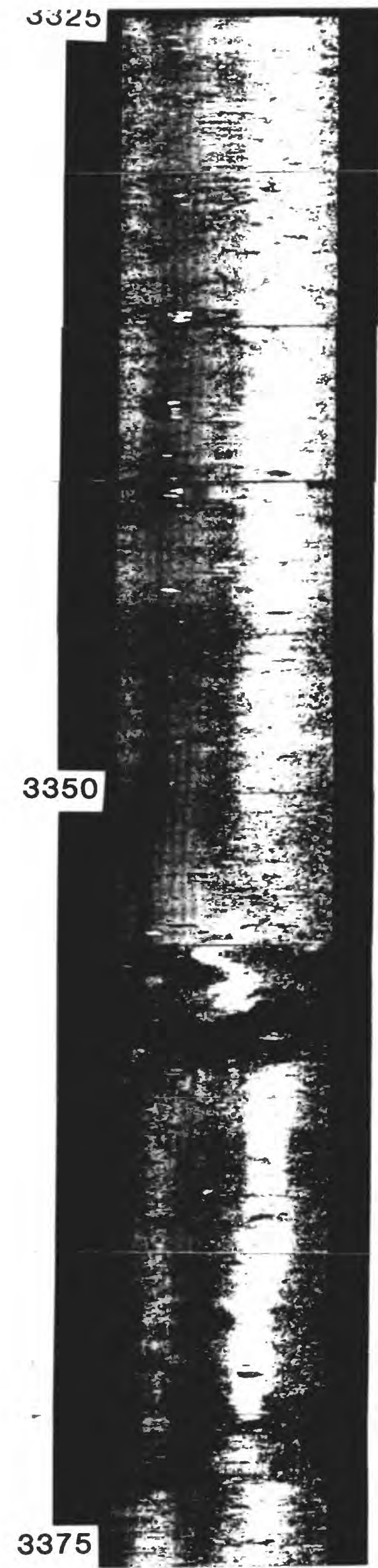

38

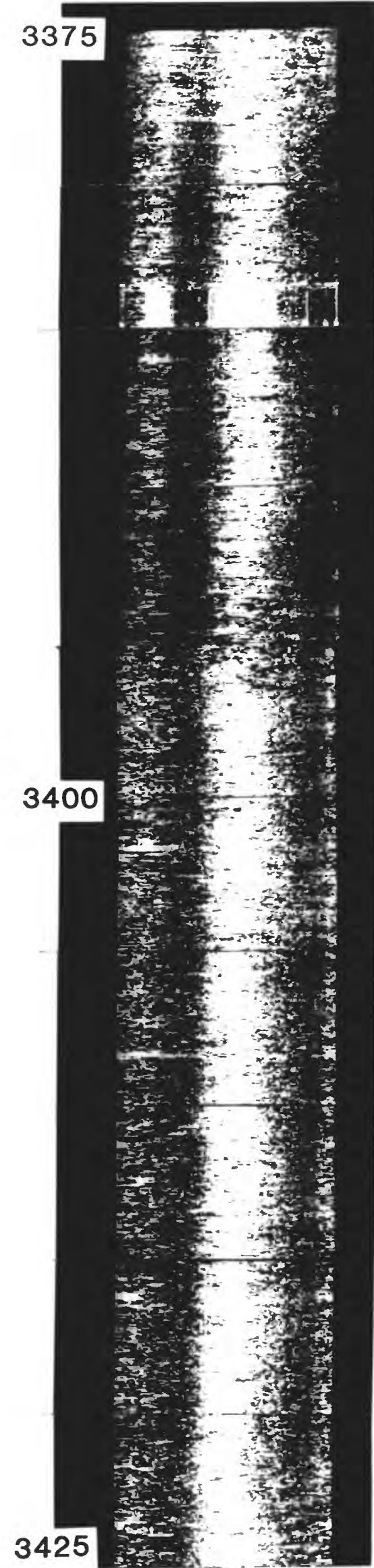




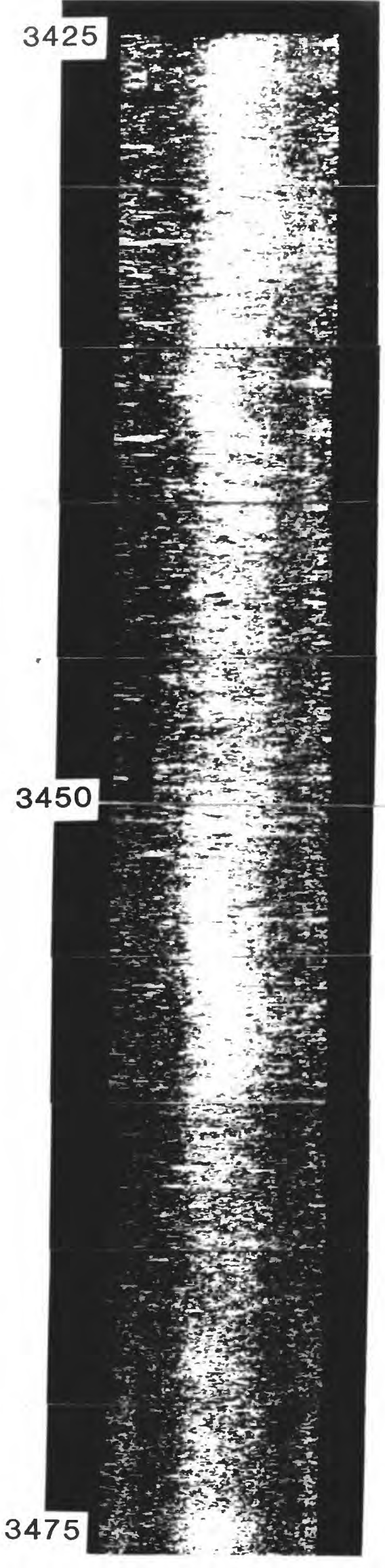

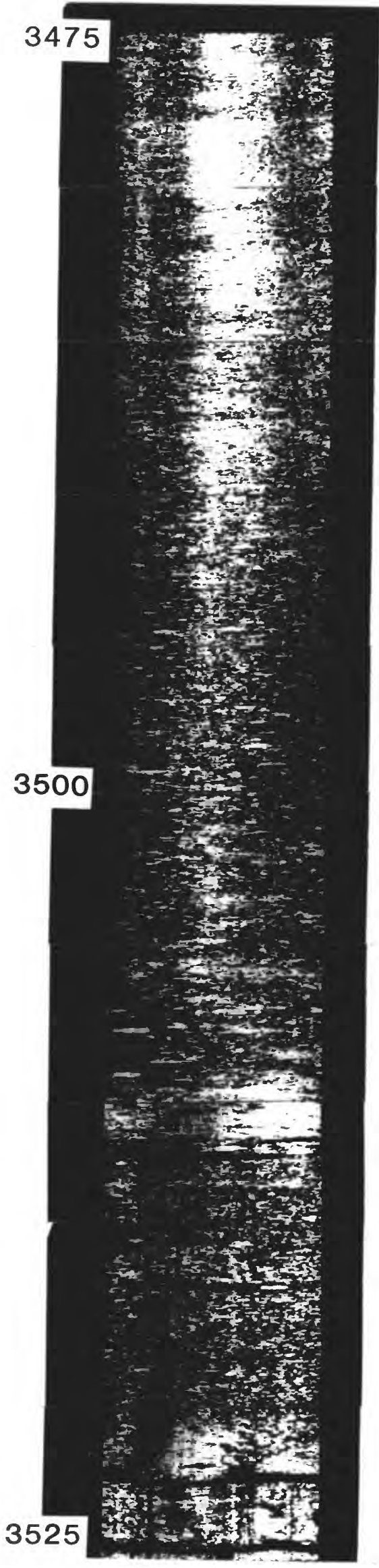

39

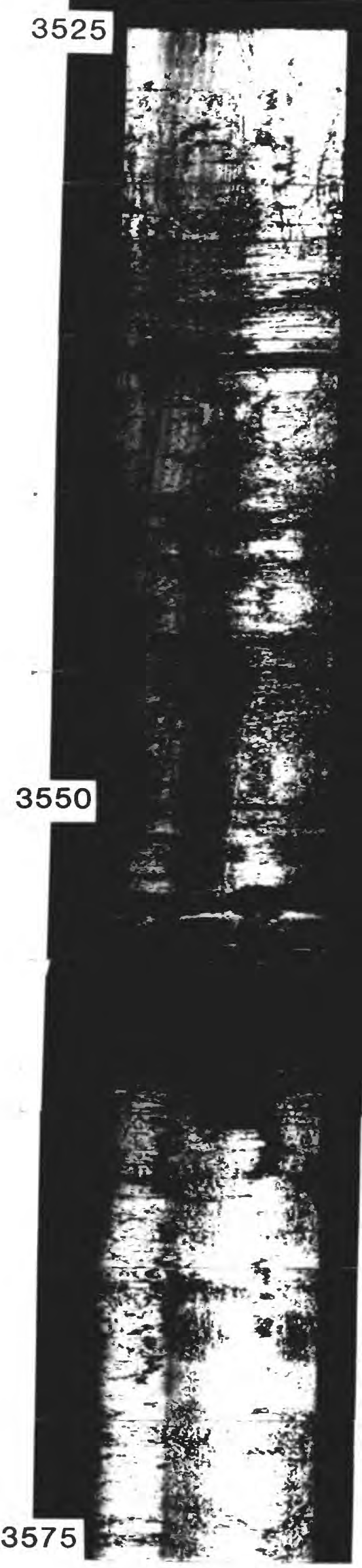



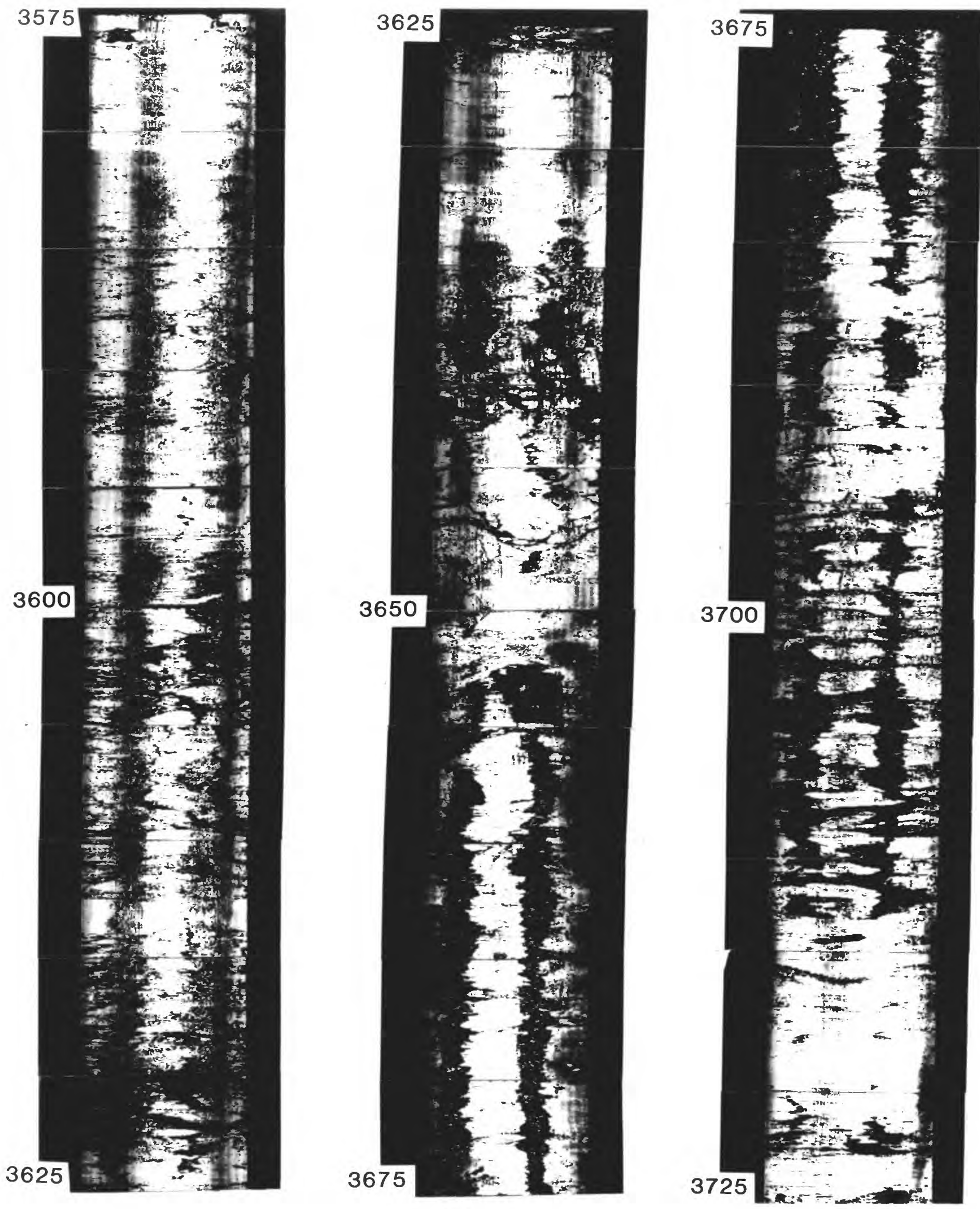

40 

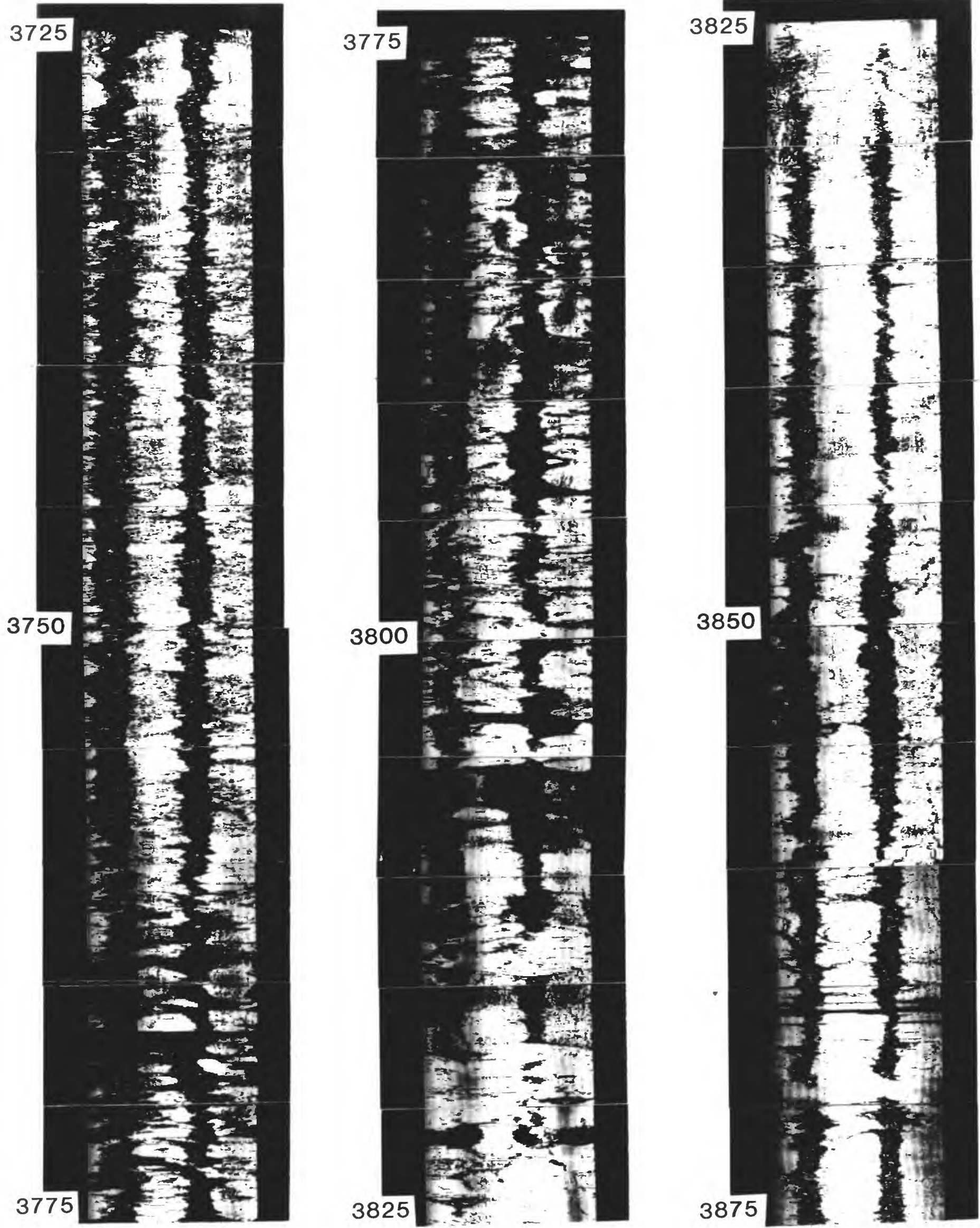

41 

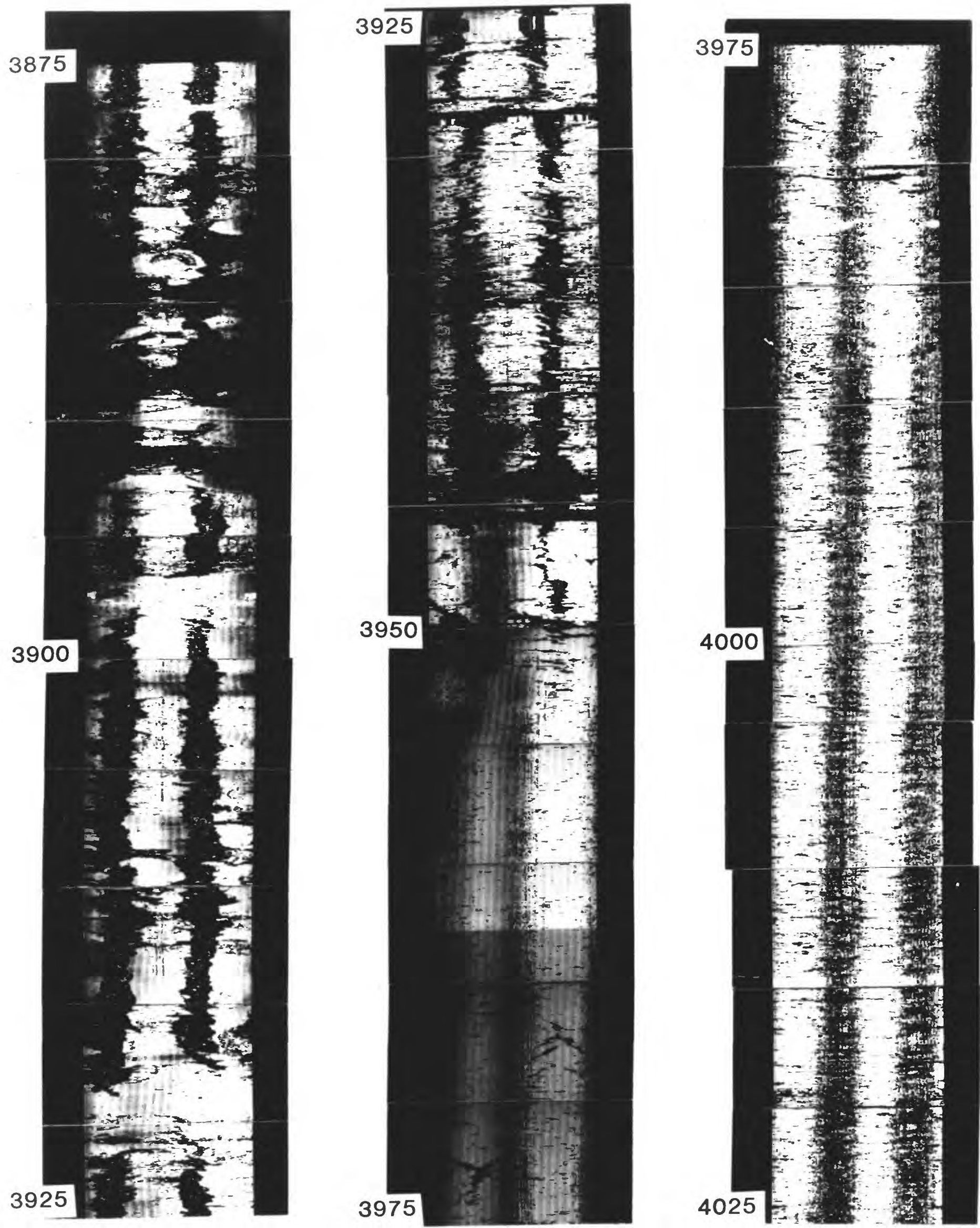

42 


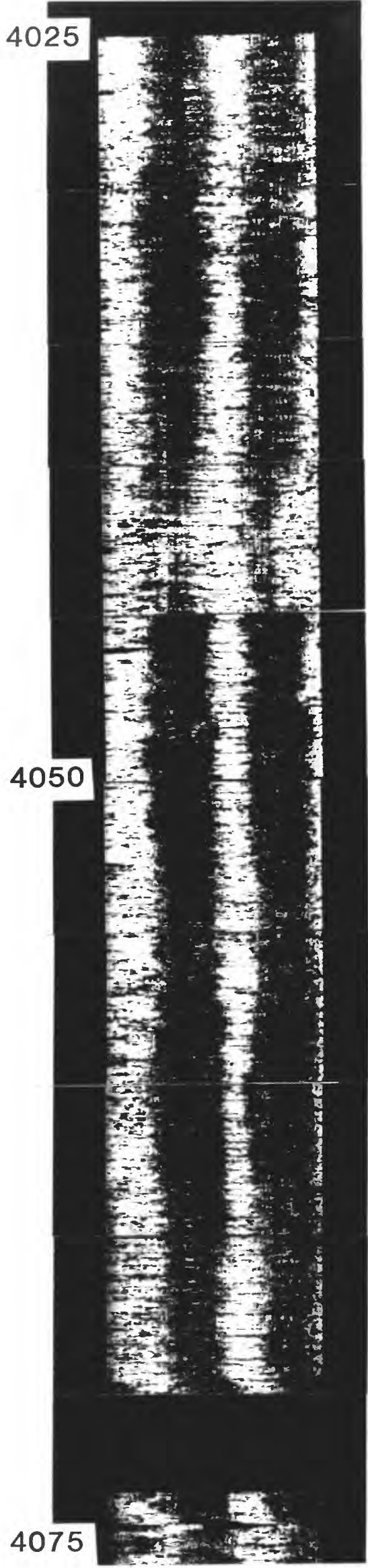

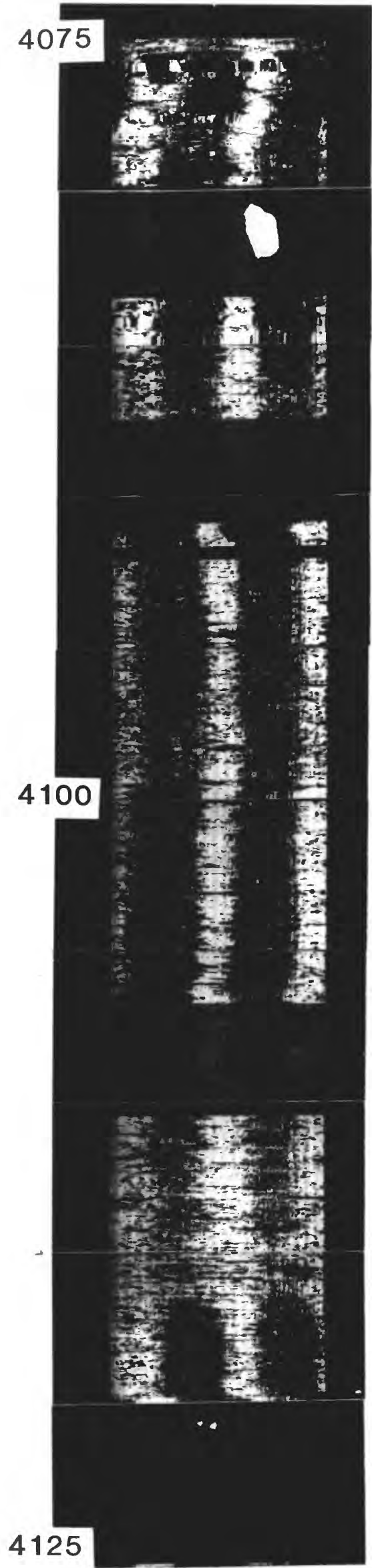

43
4125

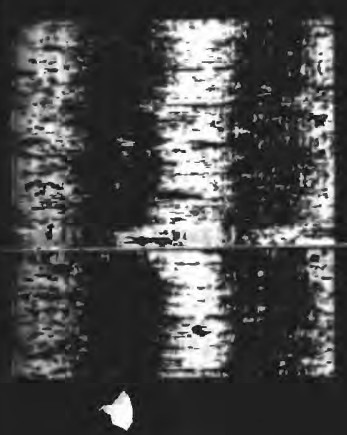

4150
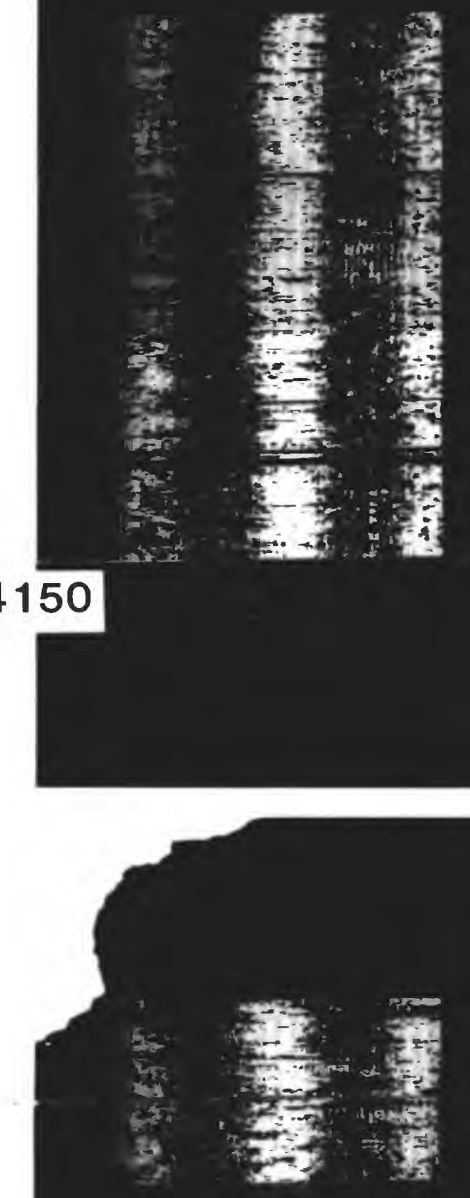

4175

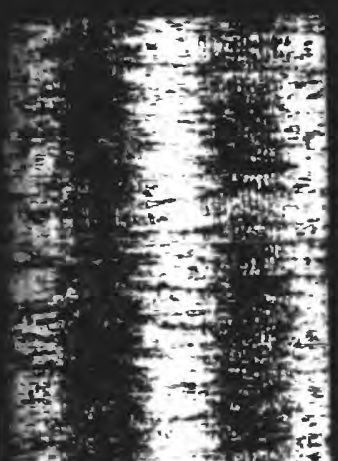



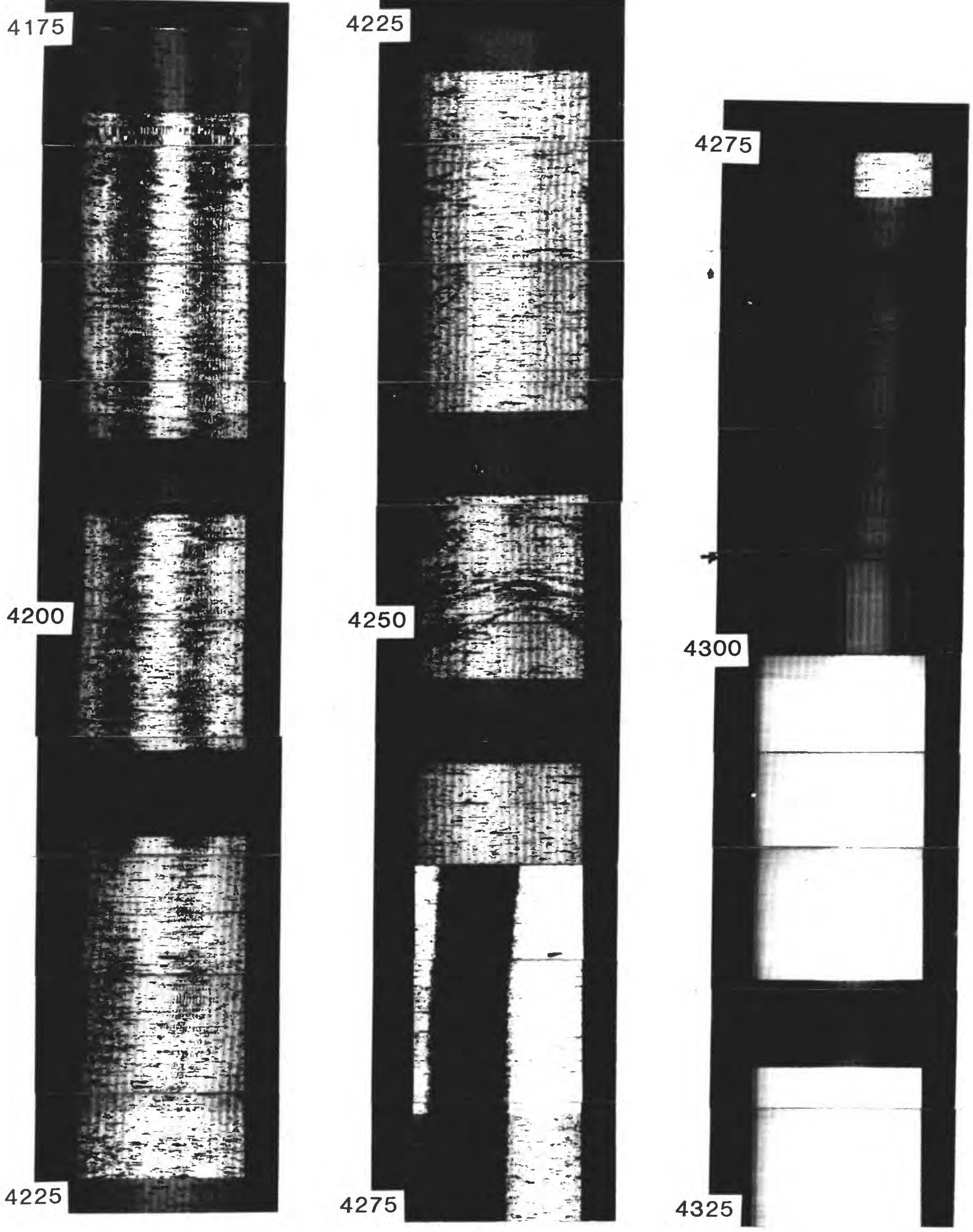

if 1 


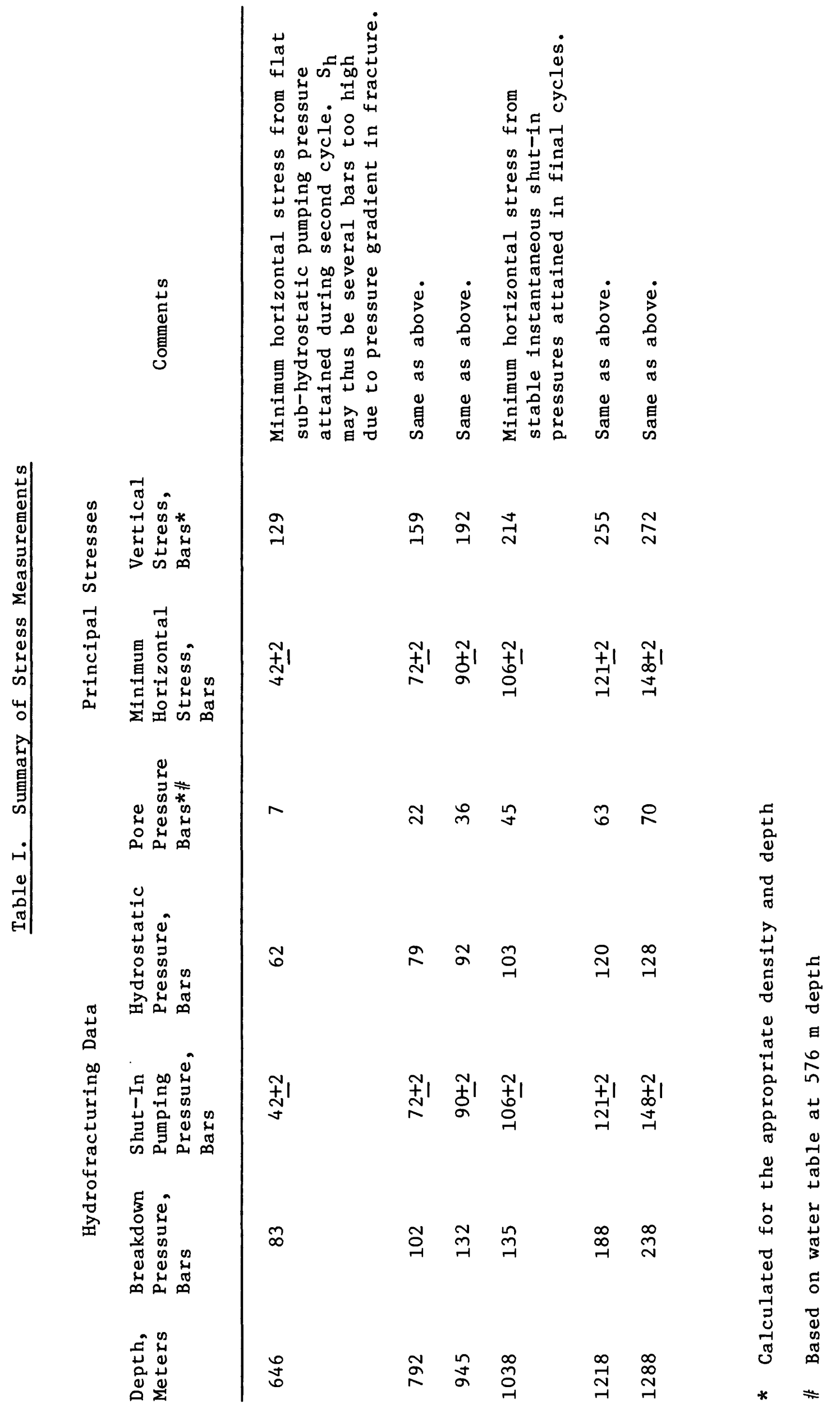


APPENDIX III

\section{Density Measurement and Vertical Stress}

The values of the vertical stress, $S_{V}$, presented in Table $I$ and in Figure 7, are calculated from the densities of the rocks in the drili nole. The estimation of these derisities is somewhat complicated, particularly for rocks in the so-called unsaturated zone. Densities may be estimated from core samples, from the density logs available for these holes, and from gravimeter measurements in the drill holes. In our judgement, the best density estimates available for use in USW-GI are those made for USW-H1 (Snyder and Carr, 1982, p. 15). USW-H1 is located $550 \mathrm{~m}$ from USW-G1 and the density distribution in the two holes should be similar. Snyder and Carr compared measurements on the core, downhole gravimeter data, and gamma-gamma logs to obtain density estimates suitable for reduction of gravity data. In Table II we present their density values for USW-HI and use these values to calculate tne vertical stress, $S_{V}$.

The hydrostatic head in hule USW-GI is an important parameter needed to estimate the effective stress and the zone of failure in Figure 7 . There is some uncertainty in this number: prior to the stress measurements the nole was cleaned and filled witn drilling mua. After tnis procedure was completed, we measured a depth to the water table of $1,695 \mathrm{ft}(516.6 \mathrm{~m})$. The current estimate used oy the USGS Water Resources Division is $1,87 \% .8 \mathrm{ft}(5 / 2.4 \mathrm{~m})$ (Rodison, oral commun., 1982), but tnis number has not been publisned. In our plot we have used a value of $1,890 \mathrm{ft}(576.1 \mathrm{~m})$, as publisiled in Open-file Report 81-1349 (Spengler et a1., 1981 ). 
TABLE II. Density Measurements in USW-HI (Snyder and Carr, 1982)

\begin{tabular}{|c|c|c|}
\hline $\begin{array}{l}\text { Depth } \\
\text { (m) }\end{array}$ & Density & $\begin{array}{c}\text { Vertical stress } \\
\mathrm{S}_{\mathrm{V}}\end{array}$ \\
\hline $0-152.4$ & 2.17 & 32.4 \\
\hline 213.4 & 1.87 & 43.0 \\
\hline 274.3 & 2.01 & 55.6 \\
\hline 335.3 & 2.04 & 07.8 \\
\hline 396.2 & 2.00 & $7 y .7$ \\
\hline 457.2 & 2.20 & $y^{\prime} 2 . y$ \\
\hline 518.2 & 1.87 & 104.1 \\
\hline 579.1 & 1.90 & 115.4 \\
\hline 640.1 & 2.10 & 128.0 \\
\hline 685.8 & 1.99 & 136.9 \\
\hline 731.5 & 2.08 & 146.2 \\
\hline 792.5 & 2.25 & 159.7 \\
\hline 853.4 & 2.13 & 172.4 \\
\hline 914.4 & 2.22 & 185.7 \\
\hline 975.4 & 2.28 & 199.3 \\
\hline 1036.3 & 2.30 & 213.0 \\
\hline 1097.3 & 2.36 & 227.1 \\
\hline 1158.2 & 2.43 & 241.0 \\
\hline 1219.2 & 2.28 & 255.2 \\
\hline 1280.2 & 2.32 & 269.1 \\
\hline 1341.1 & 2.32 & 283.0 \\
\hline 1402.1 & 2.30 & 296.8 \\
\hline 1463.0 & 2.39 & 311.1 \\
\hline 1524.0 & 2.38 & 325.3 \\
\hline 1585.0 & 2.38 & 339.5 \\
\hline $1645 . y$ & $2.3 y$ & 353.8 \\
\hline 1706.9 & 2.36 & 367.9 \\
\hline 1767.8 & 2.48 & 382.7 \\
\hline 1828.8 & 2.54 & 397.9 \\
\hline
\end{tabular}

